>>>> > STOP ON ARCHIVES

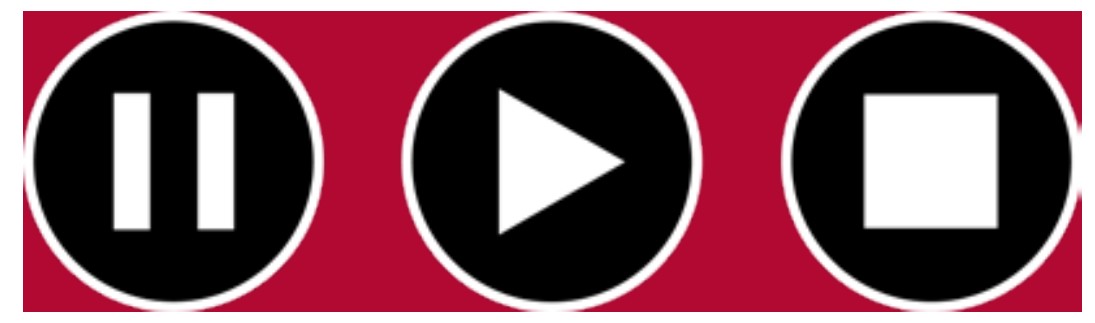

ARRÊT SUR ARCHIVES $<<<<<$ 


\title{
A Broken Screw in the Soviet System. The Life and Fate of Leonid Nikolaev
}

\author{
Andrey SOROKIN \\ Archive Director \\ The Russian State Archive of Socio-Political History (RGASPI) \\ rgaspi dr@mail.ru
}

\begin{abstract}
The tectonic change of 1917 not only disrupted the country but also placed, for a brief moment, a "little man" at the centre of "big story." Nikolaev was a typical representative of ordinary people being pushed into a corner by circumstances and deceived in their expectations by a pseudo-socialist state. The high expectations of ordinary people, who were involved by the Bolsheviks in their politics, naturally crashed into the harsh realities of the construction of socialism.

Brought to political life from social non-existence, this ordinary man soon became unnecessary to the new political regime's needs and was subject to manipulation and mobilization by the party. This is how he ended up being merged with the human mass, which was faceless to the party nomenclature. However, this ordinary man was opposed to the latter and thus became the cause of large-scale social cataclysms. He got a weapon and killed Kirov; the personification of the political power against which Nikolaev's act was directed.

In the early Soviet period, many representatives of this social stratum raised their voices in protest, even if not in a terrorist form. Many of them were physically eliminated, the rest were brought to submission. This was a demonstration of the toughness of the Bolshevik regime, which transformed into the regime of Stalin's personal power in the 1930s, involving terrorist forms of governing.
\end{abstract}

Keywords: Russian revolution, Bolsheviks, political assassination, political power, opposition, Kirov, repression, terror, Stalin.

\section{Résumé :}

Le changement tectonique de 1917 a non seulement bouleversé le pays mais il a aussi placé, pour un court instant, un « petit homme » au centre de la « grande Histoire ». Nikolaev était un représentant typique des gens ordinaires impliqués par les bolcheviks dans leur politique, qui furent acculés dans un coin par les circonstances et trompés dans leurs attentes par un État pseudo-socialiste.

Passé de l'inexistence sociale à la vie politique, cet homme ordinaire devint vite inutile aux yeux du nouveau régime politique et fit l'objet de manipulations et de mobilisations du parti. C'est ainsi qu'il finit par se fondre dans la masse, qui, pour la nomenclature du parti, n'avait pas de visage. Or cet homme ordinaire s'opposa à cette dernière et devint la cause de cataclysmes sociaux à grande échelle. Nikolaev se procura une arme et assassina Kirov, qui symbolisait le pouvoir politique, contre lequel l'acte de Nikolaev était dirigé.

Au début de la période soviétique, de nombreux représentants de cette couche sociale élevèrent leur voix pour protester, même si ce n'était pas sous une forme violente. Nombre d'entre eux furent éliminés physiquement. La dureté du régime bolchevique qui, durant les années 1930, se transforma en un pouvoir personnel de Staline, impliquait en effet des formes terroristes de gouvernement.

Mots-clés : Révolution russe, Bolcheviks, assassinat politique, pouvoir politique, oppositions, Kirov, répressions, terreur, Staline. 


\section{A Broken Screw in the Soviet System. The Life and Fate of Leonid} Nikolaev (Based on the documents of the Russian State Archive of Socio-Political History)

The assassination of Sergey Kirov (1886-1934) - member of the Politburo of the Central Committee of the All-Union Communist Party of Bolsheviks (VKP(b)) and First secretary of the Leningrad Region and City Committee, became one of the most sensational cases in Soviet History (Жуков 2000; Кириллина 2001; Бастрыкин и Громцева 2001; Никитин 2019; Knight 2000; Egge 2009; Leone 2010). On Saturday, December 1, 1934, Kirov was killed by a head-shot at $4: 30 \mathrm{pm}$ in the corridor of the third floor of the Smolny building, where the party organisation of the Leningrad region and city was located. Kirov's private office was on the same floor. His body was found by the participants of a meeting that was taking place in the office of Mikhail Chudov, the second secretary of the regional party committee. They rushed out into the corridor as soon as the shots were heard. Kirov's guard Mikhail Borisov ran up to the crime scene when it was already all over. Kirov's body was lying on the left side of the door of Chudov's office. Another man was lying unconscious with a revolver in his right hand. A notebook and a party membership card identifying the man as Leonid Nikolaev were found in the pocket of his jacket. The revolver had shot twice, but Kirov was killed by only one of the bullets. The second shot was intended for Nikolaev himself, but his suicide attempt was not successful. Later the second bullet was found below the ceiling in the corridor wall. ${ }^{1}$

It seems that in Kirov's life nothing foreshadowed what happened on December 1,1934 . On that day he had worked at home and was occupied preparing a speech, which he intended to deliver in the evening at a meeting of party activists in the Tauride (Tavricheskiy) Palace in Leningrad. The missing documents that he needed for this work were brought to him from the Smolny four times a day. Kirov was not expected to come to the party's headquarters that day and his trip to the Smolny was not planned. But at around 4:00 pm he called his driver and asked him to take him to his office.

1 Main archival collections are available in РГАСПИ, ф. 671, Ежов Николай Иванович, 1895-1940, оп. 1. Руководство Н.И. Ежовым расследованием убийства С.М. Кирова, организация репрессий в Ленинграде в отношении бывших участников зиновьевской оппозиции в других, д. 112-149; ф. 17. оп. 171, Постановления Политбюро ЦК РКП(б), ЦК ВКП(б), ЦК КПСС о деятельности антипартийных групп. 16.01.1919-01.11.1966, д. 197-202, 446, 452, 456, 457, 496. 
Upon his arrival at the Smolny he was met by the guards, including Borisov, who accompanied him personally to the place of his murder.

As Nikolaev later reported during police interrogations, he very much wanted to be present at the meeting of the party activists in the Tauride Palace in the evening of December 1, at which Kirov planned to give a speech. For this purpose, he tried to get a pass and permit from his acquaintances, who worked in the Smolny. The entrance to the building was free; the restrictions concerned only the access to the third floor, where the party leadership's offices were located, but in order to get there it was sufficient to show one's own party membership card to the guards. Nikolaev, who was arrested right after his assault and interrogated for the first time on the evening of this same day, described what happened as follows:

I left the Smolny building and walked for an hour around Tverskaya and Ochakovskaya streets and then returned to the Smolny. I went up to the third floor, proceeded to the lavatory and, when I got out, I turned left. After making two or three steps, I saw that at a distance of 15-20 paces Sergey Mironovich Kirov was approaching me on the right side of the corridor. On seeing [...] Kirov, I first stopped and turned my back on him, so when he had passed by, I looked towards his back. When Kirov had walked another 10-15 steps, I noticed that there wasn't anybody anywhere near us. Then I followed Kirov, gradually catching up with him. When Kirov turned left around the corner and headed in the direction of his office -a location that was well known to me-, there was no one in the corridor. I ran about five steps after him, took the revolver out of my pocket when running, pointed the pistol at Kirov's head and fired one shot in the back of his head. Kirov instantly fell flat on his face (See documents $1,2 \& 3)^{2}$

\section{Investigation of a crime}

Immediately after the assault, Chudov tried to call Stalin in order to report the murder, but he reached him only after calling him a second time and after he had explained the purpose of his phone call to Stalin's private secretary Aleksandr Poskrëbyshev. At that moment, Stalin was in his office surrounded by the men of his "inner circle" -i.e. Vyacheslav Molotov, Lazar Kaganovich, Kliment Voroshilov and Andrey Zhdanov. After Chudov's call, Stalin immediately summoned a meeting with Genrikh Yagoda -the Head of the NKVD (People's Commissariat for Internal Affairs), and the other members of Politburo. During this meeting Yagoda received a telegram from Filip Medved' -the Head of the OGPU-NKVD Department of Leningrad and Leningrad region, describing the circumstances of Kirov's violent death and the first steps of investigation that had been taken. At the end of the meeting, a decree was drafted that aimed at strengthening the rules

2 РГАСПИ, ф. 17, оп.171, д, 197, л.3; ф. 671, оп. 1, д. 113, л. 12. 
of punishment for terrorist attacks. On December 3, this decision was formalised as a decree [postanovlenie] of the Politburo. ${ }^{3}$

By December 1 , the respective articles were already added to the USSR's Criminal Code. (Постановление 1934, 1). At the same time, extrajudicial punitive bodies were established. Late in the evening, Stalin left for Leningrad, accompanied by members of the Politburo (Anastas Mikoyan, Vyacheslav Molotov, Lazar Kaganovich, Andrey Zhdanov), and a group of investigators and heads of the OGPU. Stalin personally took part in a number of interrogations of suspected persons, including Nikolaev and his wife Milda Draule.

Apart from Nikolaev and his relatives, another group of people was arrested. They were accused of having been involved in the conspiracy to assassinate Kirov. Both political and factual responsibility for the murder was attributed to the members of the so-called "Leningrad centre" (Трижды презренные 1934, 1; Кольцов 1934, 3). Except Nikolaev, some thirteen other people were accused of affiliation with this circle. Most of them were Nikolaev's acquaintances. Meanwhile it took some time until Stalin chose the direction of his attack. At the beginning, the secret service investigators apparently did not receive any instructions from above and started with their own interpretations of what had happened. Yakov Agranov -First Deputy of the People's Commissar of the NKVD - who was appointed instead of Filip Medved' as Head of the Leningrad Department of the NKVD, in his report of December 4 called two of the suspects that had been interrogated a "Trotskyist" and an "Anarchist" (See document 4). On the same day, Pravda published a report about the first arrests of members of the "White Guards" (В народном Комиссариате 1934, 1). Subsequently several dozen people were arrested and executed in Moscow, Leningrad, Kiev and Minsk, but the government did not reveal whether or how these measures were related to the case of Kirov's assassination.

\section{The start of the purges}

The situation changed only ten days later. On December 15, Zhdanov, who was assigned to succeed Kirov as party chief of Leningrad, publicly accused former members of the political opposition (political supporters of Grigoriy Zinov'ev) of having plotted Kirov's murder. During the following days, in a number of party documents and editorial articles of party newspapers, Zinov'ev, Lev Kamenev and other men were presented as the people who had inspired the assault, but no further results of the authorities' investigations were revealed.

3 РГАСПИ, ф. 17, оп.162, д. 17, л. 87. 
Finally, on December 22, the relevant report of the NKVD was published declaring Nikolaev a member of the terrorist "Leningrad center" (В народном комиссариате 1934, 1). The crime's investigation was completed quickly. On December 28-29, the Military Collegium of the USSR Supreme Court already convened for a special session and issued a judgement. According to the court's decision, fourteen accused men were found guilty and shot on the same day. Stalin edited the press release with his own hand (See document 5).

Charges of having been involved in Kirov's murder would soon become a useful, "universal tool" in Stalin's political strategy. Soon after his attack on the opposition in Leningrad, Stalin decided to launch another strike at his political opponents in Moscow. In January 1935, the country learned about the alleged existence of a "Moscow centre." (Закрытое письмо 1935, 95-100). The "Case of the 137" was prepared. In this context, Kamenev and Zinov'ev, former members of the Politburo and two of Lenin's closest associates, were accused of bearing political responsibility for Kirov's murder. (Обвинительное заключение 1934, 3). Shortly afterwards, at the third Moscow show trial, the so called "Maverick rightists" (supporters of Nikolay Bukharin) were also charged of having been involved in Kirov's assassination. Moreover, in 1938, Lev Trotskiy was declared in the Short Course [Краткий курс] as the master mind who had plotted Kirov's execution (История ВКП(б) 1938, 312). During the years of the Great Terror, a considerable number of people who were arrested and disappeared were accused of involvement in the "Kirov case," including Genrikh Yagoda and his colleagues (Эгге 2011, 70). This event gave rise to the later version of a Chekist plot, who manipulated Nikolaev either on their own initiative or to carry out Stalin's will. At the beginning of the Cold War, Nikolaev became in the Soviet official narrative an "agent of imperialistic intelligence services." This is reflected, for example, in the relevant entry in the Great Soviet Encyclopedia (Большая советская энциклопедия 1953, 113).

\section{Versions and Interpretations}

An outstanding authority of US-American Sovietology, Robert Conquest, once called Kirov's assassination in 1934 "The Murder of the Century" (Conquest 1990, 37). It is generally accepted (and it has not been discounted) that the killing of Kirov set in motion the wheels of repression and the Great Terror, in the course of which during the four years of 1935-1938, about two million Soviet people were arrested, and approximately 700,000 of them were shot. But still we can find in the scholarly literature a large number and variety of interpretations, rumours, and speculations about the causes of the murder and its real or alleged 
perpetrators. By using this murder as an excuse for or as an explanation for the physical elimination of his political rivals and directly declaring the need for retaliation, Stalin acted in such a way shortly after the event as to be associated with the organisation of the plot. As in other cases, this version of the story also entered Soviet folklore and the following four-line folk rhyme (chastushka): "Oh, those little cucumbers and tomatoes! Stalin killed Kirov in the little corridor!" (Душенко 2006).

Nikita Khrushchev was the first prominent politician in the Soviet Union to publicly articulate this version of the plot in his famous "confidential" report to the $20^{\text {th }}$ Congress of the Communist Party of the Soviet Union in February 1956 (Доклад Н.С. Хрущева 2002, 69-70). There can be no doubt that Khrushchev aimed at using this interpretation to dethrone Stalin and distance himself from his cult of personality. Kirov was just an ordinary party leader and nothing made him different from others. He was neither a reformer nor a leading figure of the anti-Stalinist opposition. Today, there remains little doubt about this assessment of Khrushchev's attitudes and political mindset. Nevertheless, it was the democratically oriented Soviet public that insisted on the truth of Khrushchev's interpretation of the Kirov case in the 1950s-1970s. At that time, Soviet people had not totally lost their faith in socialist ideals and values, and the country was in desperate need of positive political figures from Stalin's period of Soviet history.

Today it is clear that Khrushchev, like Stalin before him, perceived the "Kirov case" as a suitable and useful instrument in his fight for power. In this way he followed the path beaten by Stalin (dead by this time) and the members of his closest "inner circle"-Molotov, Malenkov, and Kaganovich, who had not given up their competition for power with the new party leader. Like the whole program of "de-Stalinisation," the "Kirov case" was used by Khrushchev merely for political purposes in the context of his fight with his political rivals. In the meantime, Khrushchev's strategy had a significant political subtext. By presenting the USSR's current problems of political, social and economic development as a result of repression and terror in the 1930s and 1940s and underscoring Stalin's responsibility for mistakes in previous decades, Khrushchev was protecting the legitimacy of the political regime, as well as that of the entire socio-economic and political system.

The case of Kirov's murder was finally closed by one of the numerous commissions that were set up by Mikhail Gorbachev in September 1987. Its task was to further investigate historical source materials related to the political repression of the 1930s, 1940s and early 1950s. The commission was chaired by 
the "architect of perestroika" Aleksandr Yakovlev - a member of the Politburo (Известия ЦК 1989, 109-110). In June 1990, the commission came to the following conclusion in the case of Kirov's murder:

Analysis of all documents and materials gives grounds for the conclusion that the terrorist act against Kirov on December 1, 1934, was prepared and implemented by Nikolaev alone (Реабилитация: как это было 2004, 460).

Until today Khrushchev's version of the Kirov case as outlined in his "secret speech" of 1956 has been frequently reproduced in different variations by publicists and historians who at the same time have ignored a considerable number of historical documents relating to this matter that have recently become available to scholars and the public. Documents of great historical value, including the transcripts of the interrogation of Nikolaev and the witnesses, documents of the judicial investigation and other source material are kept in the Russian State Archive of Socio-Political History (RGASPI) in the "Politburo collection" (See documents 6\&7) and "Ezhov collection," and today they are available for researchers. ${ }^{4}$

\section{Why did Nikolaev shoot Kirov?}

Among the variety of interpretations circulating about the Kirov case and Nikolaev's motives in committing this crime, one is of particular interest. In his well-known Conversations with Feliks Chuev [Сто сорок бесед с Молотовым], Molotov once mentioned the following: "Women have nothing to do with it [Nikolaev's assault on Kirov]” (Чуев 1991, 310). However, according to a wellinformed person, Pavel Sudoplatov, who formerly held key positions in the Soviet security bodies and who finished his career in the NKVD and Ministry of Internal Affairs with the rank of lieutenant-general, all the leaders of the NKVD were well aware of Kirov's love affairs. Sudoplatov is hinting at Nikolaev's wife, Milda Draule, being one of Kirov's numerous mistresses:

The Communist party that is expecting irreproachable behaviour from its members in private life, may by no means declare publicly, that one of its pillars [...] actually was involved in love affairs with married women (Судоплатов 1994, 51).

According to recollections of eye-witnesses, when Nikolaev was arrested after Kirov's death, he shouted: "I took my revenge on him" (Роговая 1992, 68). Moreover, one of Nikolaev's diary entries may be read as indirect evidence for this version of the story: "M. [Milda], you should have foreseen many things, but you refused to do so."5

4 РГАСПИ, ф. № 671, Ежов Николай Иванович, оп. 1.

5 Ibid. 
As a matter of fact, there are no other records to support this history of events, neither in Nikolaev's diary nor in other notes left by him. Today it is almost impossible to either confirm or refute this version. Whether or not Milda Draule played any role in the Kirov case, in full compliance with the logic of the times, a tragic death awaited her. Like her husband, she was shot (as were the other members of Nikolaev's family) shortly after his execution (See document 8).

So, the question that still requires an answer is that of Nikolaev's motives. Who was this person? Was he "the infuriated philistine, who imagined himself a proletarian," as he is described in one of the background notes of the Central Committee apparatus in the late 1950s? The Party commission which investigated the case in the late 1950s recorded: "Surely, he was insane, epileptic, arrogant and embittered against the party and the Soviet state."' This statement appears to be true. The assassin, who proved unable to kill himself, who fainted either due to what he had done, or due to the kickback of the revolver to his head, who became hysterical for almost a day, was not well suited for the role of hero or conspirator to whom such a delicate mission might have been entrusted.

\section{Who was Nikolaev?}

As a historical "phenomenon," Nikolaev is an extremely interesting figure. Nikolaev was an employee of a branch of the Institute of History of the All-Union Communist party of Bolsheviks (VKP(b)). At the end of March 1934, he was expelled from the party due to his refusal "to work on transport" (See documents 9 \& 10). ${ }^{8}$ The obligation to "work on transport" was imposed by the so-called mobilisation campaign, which was promoted by one of the VKP(b) local party organisations. As a consequence, he lost his job, which had been beneficial from the material point of view. He explained his refusal to follow the party instructions by referring to his own sickness and his family commitments (there were two small children in Nikolaev and Draule's family, and his wife's mother financially depended on Nikolaev's family). ${ }^{9}$ Apparently, Nikolaev was a good family man. "He took care of the children, read books and was very interested in history," his wife said later during interrogation. ${ }^{10}$ But shortly afterwards she revealed something that might have alluded to her husband's personal flaws:

Several times he wrote his autobiography, and one time he re-wrote it [even] in

6 РГАСПИ, ф. 671, Ежов Николай Иванович, оп. 1.

7 Ibid.

8 РГАСПИ, ф. 589, оп. 3, д. 8500, л. 30, 35. For further information about labour mobilisations ("to work on transport” [rabotat' na transporte]) see: Арнаутов 2018, 96-168).

9 РГАСПИ, ф. 671, оп. 1, д. 114, л.1.

10 Ibid., л.4-5. 
capital letters [...] he explained to me that he wanted his elder son Marx to read and study it. He intended his autobiographical narrative to be written in a literary language. For the purpose of learning from others and their style he read Tolstoy, Gorky and other authors.

Moreover, Nikolaev kept a diary, which, according to his wife, "began to reflect his decadent moods, [finally] he was haunted by fear of being unable to maintain his family financially." 11

Nikolaev protested against the decision to exclude him from the party and he succeeded in turning the verdict into a severe reprimand for his behaviour (See documents $10,11 \& 12$ ). He tried to reverse even this decision, but the Smolny (i.e. the regional party committee) finally confirmed it. Offended, Nikolaev addressed a protest note to the Central Committee of the VKP(b), but his case was never considered. From that moment on until his arrest in December 1934 he was not engaged in any regular work. He declined various job offers, considering them unacceptable, because the salary there was significantly less than his previous earnings. It is worth noting that considerable attention was paid to Nikolaev by party officials, especially given that at that time there was a sharp increase in the various appeals, complaints and denunciations addressed to the party, the Soviet and trade union bodies and mass media, that were provoked and encouraged by the authorities (Nérard 2004).

During her interrogation Nikolaev's wife reported that her husband "suffered from neurasthenia and heart attacks" and from depressions after his exclusion from the party. ${ }^{12}$ Judging by Nikolaev's diaries and the testimony of his wife, Nikolaev conceived the assassination of Kirov as a sign of protest against the policy of the "party and the Soviet state." 13 There is some evidence that Nikolaev's psychophysiology may have been characterised by hysterical features.

A long while after Nikolaev had regained consciousness, he was shouting and talking gibberish, and only the next morning he declared: "my shot was heard all over the world" [...] After asking him repeatedly: "Nikolaev! Who incited you to make this shot?," he got into hysterics and started shouting, but gave no answer. ${ }^{14}$

Today Nikolaev's explanations appear quite logical and reasonable. In October 1934, he had written a letter to the Central Committee containing his complaints and grievances:

For us, the working people, there is no free access to life, to work, to study [...] We

11 Ibid., л.19-20.

12 Ibid., л.1-2.

13 Ibid., л.132-133.

14 Ibid. 
moved into a new apartment, but an exorbitant price is charged for it. Nothing can save me. ${ }^{15}$

In other papers he left the following notes:

[...] Thousands of generations will go by, but the idea of communism will not be realised [...] I attack with the same power that I used to defend all that is new.

During the interrogations, Nikolaev's wife described in detail his anti-Soviet moods:

Nikolaev accused the Central Committee of the All-Union Communist party of Bolsheviks of pursuing a militaristic policy, spending huge amounts of money on the defense defence of the country, building military plants and making a fuss over an imminent attack on the USSR at a time when no war was pending. In addition, this noise was designed to divert the attention of the USSR's working people from the difficulties caused by the mistaken policy of the Central Committee [...] This particular mood and bitterness against the party apparatus were especially acute when he was expelled from the party, which ultimately led to committing a terrorist act against Comrade Kirov. ${ }^{16}$

The Soviet leader-cult reached its apogee in the early 1930s. After the murder of Kirov, the Soviet Union transformed itself into the regime of one man's personal power. It comes as no surprise that Kirov was perceived by Nikolaev as a personification of the detested Soviet regime:

He [Nikolaev] testified, that he considered the murder of Kirov a "warning signal" for the party concerning their unfair attitude toward a human being and he believed that he had performed a "historical mission" (Роговая 1992, 68).

Exaggerated expectations of the masses of ordinary people who had been involved by Bolsheviks in grand policy in 1917 naturally collapsed in the face of the realities of so-called socialist construction.

\section{A representative of ordinary Soviet people}

The tectonic shift of 1917 not only caused upheaval in the country, but for a short while it made the little man a visible subject of history. In addition, revolution armed him in the literal sense of the word. However, Nikolaev was different from Eugene in Pushkin's Bronze Horseman [Медный всадник]. Another era had begun. Nikolaev was a typical representative of the ordinary Soviet people, a man who was driven into a corner by circumstances of daily life, disappointed in his expectations by a pseudo-socialist state, which always promised but never delivered a glorious future. However, Nikolaev, brought to

15 Ibid.

16 Ibid., л.133.

CONNEXE $5 \mid 2019$

STOP ON ARCHIVES - ARRÊT SUR ARCHIVES 
political life from social non-existence, was not welcomed by the new political regime as a self-reliant subject of the historical process, despite all its political rhetoric and propaganda. At the same time, this ordinary man did not want to become an object of manipulation and party mobilisations and refused to merge with the masses, which were faceless for the party nomenclature. Thus, he became the person who incidentally triggered a whole series of social cataclysms.

In the early Soviet period, many representatives of this social stratum raised their voice in protest, but most of them not in such a violent way as Nikolaev. Many of them were physically eliminated; others were forced into submission. This result was achieved by various means, including by demonstrating the toughness of the Bolshevik regime, which turned into the regime of Stalin's personal power in the 1930s, a man who easily resorted to terrorist forms of governing.

\section{Bibliographical references}

Conquest, Robert. 1990. The Great Terror. A Reassessment. Oxford: Oxford University Press.

Egge, Åsmund. 2009. Kirov-gåten Mordet som utløste Stalins terror. Oslo: Unipub.

Knight, Amy. 2000. Who Killed Kirov? The Kremlin's Greatest Mystery. New York: Hill and Wang.

Leone, Matthew E. 2010. The Kirov Murder and Soviet History. New Haven, CN: Yale University Press.

Nérard, Francois-Xavier. 2004. Cinq pour cent de vérité, la dénonciation dans l'URSS de Staline. Paris: Tallandier.

Бастрыкин, А., и О. Громцева. 2001. Тени исчезают в Смольном. Убийство Кирова. СанктПетербург: Европейский Дом.

“В народном Комиссариате Внутренних Дел СССР.” 04.12.1934. Правда 333 (6219): 1.

“В народном комиссариате Внутренних дел СССР.” 22.12.1934. Правда 351 (6237): 1.

Доклад Н.С. Хрущева о культе личности Сталина на ХХ съезде КПСС: Документы. 2002.

Москва: Политическая энциклопедия (РОССПЭН).

Душенко, К.В. 2006. Словарь современных цитат 112. Москва: Эксмо.

Жуков, Ю.Н. 2000. “Следствие и судебные процессы по делу об убийстве Кирова.” Вопросы истории 2: 33-51.

“Закрытое письмо ЦК вКП(б) 'О террористической деятельности троцкистскозиновьевского блока’ 18.01.1935.” 1989. Известия ЦК КПСС 8: 95-100.

История Всесоюзной коммунистической партии (больщевиков). Краткий курс. 1938. Москва: Госполитиздат.

Кириллина, А. 2001. Неизвестный Киров. Москва: Олма-пресс.

“Киров.” 1953. In Большая советская энцииклопедия. Том 21. 2-е издание: 113.

Кольцов, М. “Убийцы из “Ленинградского центра.”” 22.12.1934. Правда 351 (6237): 3. 
Нерар, Франсуа-Ксавье. 2011. Пять процентов правды. Разоблачение и доносительство в сталинском СССР. 1928-1941. Москва: Политическая энциклопедия (РОССПЭН).

Никитин, Р. 2019. Киров - первый, Сталин - второй. Дело родственников Леонида Николаева. Документы и расследования. Москва: Политическая энциклопедия (РОССПЭН).

“Об образовании комиссии Политбюро ЦК КПСС по дополнительному изучению материалов, связанных с репрессиями, имевшими место в период 30-40-х и начала 50-х годов.” 1989. Известия ЦК КПСС: 107-121.

“Обвинительное заключение по делу Николаева Л.В., Котолынова И.И., Мясникова Н.П., Шатского Н.Н., Мандельштама С.О., Соколова Г.В., Звездова В.И., Юскина И.Г., Румянцева В.В., Антонова Н.С., Ханик Л.О., Толмазова А.И., Левина В.С. и Сосицкого Л.И., обвиняемых в преступлениях, предусмотренных ст. ст. 58-8 и 58-11 Уг. Код. РСФСР.” 30.12.1934. Правда 356 (6242): 3.

“Постановление Центрального Исполнительного Комитета Союза СсР. О внесении изменений в действующие уголовно-процессуальные кодексы союзных республик.” 5.12.1934. Правда 334 (6220): 1.

Реабилитация: как это было. Документы Президиума ЦК КПСС и др. материалы. В 3 mомах. 2004. Том 3 (Середина 80-х - 1991 г.). Москва: Материк.

Роговая, Л.А. “Записка П.Н. Поспелова об убийстве Кирова. Поспелов П.Н. Материалы к вопросу об убийстве С.М. Кирова.” 1992. Свободная мысль 8: 68.

Социальная мобилизация в сталинском обществе (конец 1920-х - 1930-е г2.). 2018. С.А. Красильников (сост.). Москва: РОССПЭН

Судоплатов, П. 1994. “Нежелательный свидетель.” Огонек 42-43: 51.

“Трижды презренные.” 22.12.1934. Правда 351 (6237): 1.

Чуев, Ф. 1991. “Сто сорок бесед с Молотовым.” Из дневника Ф. Чуева. Москва: Терра.

Эгге, Ослунд. 2011. Загадка Кирова: убийство, развязавшее сталинский террор. Москва: Политическая энциклопедия (РОССПЭН). 
Andrey Sorokin - A Broken Screw in the Soviet System. The Life and Fate of Leonid Nikolaev

Перечень документов РГАСПИ по делу об убийстве С.М. Кирова (выборка);

09.04.2020

\begin{tabular}{|c|c|c|}
\hline & Название & \\
\hline документ 1 & $\begin{array}{l}\text { Протокол допроса Л.В. Николаева. } 3 \text { декабря } 1934 \text { г. } \\
\text { Заверенная копия. }\end{array}$ & РГАСПИ. Ф. 17. Оп. 171 Д. 197. Л. 2-3. \\
\hline документ 2 & $\begin{array}{l}\text { Протокол допроса монтера хозяйственной части } \\
\text { Ленинградского обкома С.А. Платоча. } 1 \text { декабря } 1934 \text { г. } \\
\text { Заверенная копия. }\end{array}$ & РГАСПИ. Ф. 17. Оп. 171. Д. 197. Л. 13. \\
\hline документ 3 & $\begin{array}{l}\text { Протокол допроса комиссара оперативного отдела УНКВД } \\
\text { по Ленинградскому военному округу Борисова. } \\
1 \text { декабря } 1934 \text { г. Заверенная копия. }\end{array}$ & РГАСПИ. Ф. 17. Оп. 171. Д. 197. Л. 25. \\
\hline документ 4 & $\begin{array}{l}\text { Сопроводительная записка заместителя наркома } \\
\text { внутренних дел СССР Я.С. Агранова секретарю И.В. } \\
\text { Сталину к материалам дела Л.В. Николаева. } 4 \text { декабря } \\
1934 \text { г. Подлинник. }\end{array}$ & РГАСПИ. Ф. 17. ОП. 171. Д. 197. Л. 1 \\
\hline документ 5 & $\begin{array}{l}\text { Проект сообщения для печати о результатах } \\
\text { предварительного расследования дела об убийстве С.М. } \\
\text { Кирова. [Не ранее } 20 \text { декабря } 1934 \text { г.] Подлинник. Правка } \\
\text { красным и простым карандашом - автограф И.В. Сталина. }\end{array}$ & РГАСПИ. Ф, 17. Оп. 171. Д. 200. Л. 56-58 \\
\hline документ 6 & $\begin{array}{l}\text { Обложка архивного дела с материалами по делу об } \\
\text { убийстве С.М. Кирова за 13-16 декабря } 1934 \text { г. }\end{array}$ & РГАСПИ. Ф. 17. ОП. 171.Д. 198. \\
\hline документ 7 & $\begin{array}{l}\text { Обложка архивного дела с материалами по делу об } \\
\text { убийстве С.М. Кирова за 21-26 декабря } 1934 \text { г. }\end{array}$ & РГАСПИ. Ф. 17. ОП. 171. Д. 200. \\
\hline документ 8 & $\begin{array}{l}\text { Протокол допроса М.П. Драуле (жены Л.В. Николаева). } \\
20 \text { декабря } 1934 \text { г. Заверенная копия. }\end{array}$ & РГАСПИ. Ф. 17. Оп. 171. Д. 200. Л. 26-27. \\
\hline документ 9 & $\begin{array}{l}\text { Выписка из протокола заседания партколлегии } \\
\text { Ленинградской области с решением о подтверждении } \\
\text { вынесения строгого выговора Л.В. Николаеву «за } \\
\text { недисциплинированность и обывательское отношение к } \\
\text { парт[ийной] мобилизации». } 2 \text { июля } 1934 \text { г. Подлинник. }\end{array}$ & РГАСПИ. Ф. 589. ОП. З. Д. 8500. Л. 30 \\
\hline документ 10 & $\begin{array}{l}\text { Опросный лист Ленинградской областной контрольной } \\
\text { комиссии со сведениями о Л.В. Николаеве. Апрель } 1934 \\
\text { г. Подлинник. }\end{array}$ & РГАСПИ. Ф. 589. ОП. 5. Д. 8500. Л. 25 \\
\hline документ 11 & $\begin{array}{l}\text { Апелляционное заявление Л.В. Николаева в } \\
\text { Ленинградскую областную партколлегию с просьбой } \\
\text { снять с него строгий выговор за нарушение партийной } \\
\text { дисциплины. } 2 \text { июня } 1934 \text { г. Подлинник. Автограф. }\end{array}$ & РГАСПИ. Ф. 589. Оп. З.Д. 8500.Л. 27-28 \\
\hline документ 12 & $\begin{array}{l}\text { Протокол № } 4 \text { экстренного заседания партийного } \\
\text { комитета Ленинградского Института истории ВКП(б) } \\
\text { с рассмотрением вопроса «О проступке т. Николаева». } \\
31 \text { марта } 1934 \text { г. Подлинник. }\end{array}$ & РГАСПИ. Ф. 589. Оп. З.Д. 8500.Л. 20-200б. \\
\hline
\end{tabular}


Andrey Sorokin - A Broken Screw in the Soviet System. The Life and Fate of Leonid Nikolaev

RGASPI document list on the murder of S.M. Kirov (sample) ; 09.04.2020

Translated by Annick Valleau (UNIGE)

\begin{tabular}{|c|c|c|}
\hline & Document description & \\
\hline Document 1 & $\begin{array}{l}\text { Minutes of L.V. Nikolaev's interrogation. December 3, } 1934 . \\
\text { Certified copy. }\end{array}$ & RGASPI. f. 17.op. 171 d. 197. 1. 2-3 \\
\hline Document 2 & $\begin{array}{l}\text { Minutes of S.A. Platoch's interrogation, field engineer of the } \\
\text { Leningrad Regional Committee maintenance department. } \\
\text { December 1, 1934. Certified copy. }\end{array}$ & RGASPI. f.17.op. 171.d. 197.1. 13. \\
\hline Document 3 & $\begin{array}{l}\text { Minutes of Borisov's interrogation, Operations Commissioner } \\
\text { of the UNKVD Division in the Leningrad Military District. } \\
\text { December 1, 1934. Certified copy. }\end{array}$ & RGASPI. f. 17.op. 171. d. 197.1. 25. \\
\hline Document 4 & $\begin{array}{l}\text { Accompanying note to the materials of the L.V. Nikolaev case } \\
\text { by Deputy of the USSR People's Commissariat for Internal } \\
\text { Affairs Ya.S. Agranov for the attention of I.V. Stalin's secretary. } \\
\text { December 4, 1934. Original. }\end{array}$ & RGASPI. f. 17.op. 171.d. 197.1. 1 \\
\hline Document 5 & $\begin{array}{l}\text { Draft press release on the results of the preliminary investigation } \\
\text { into the murder of S.M. Kirov. [Not before December 20, 1934.] } \\
\text { Original. Editing in red pencil - I.V. Stalin's autograph. }\end{array}$ & RGASPI. f. 17. op. 171. d. 200.1.56-58 \\
\hline Document 6 & $\begin{array}{l}\text { Cover of the archive record with the materials of 13-16 December } \\
1934 \text { on the murder of S.M. Kirov. }\end{array}$ & RGASPI. f. 17.op. 171.d. 198 \\
\hline Document 7 & $\begin{array}{l}\text { Cover of the archive record with the materials of 21-26 December } \\
1934 \text { on the murder of S.M. Kirov }\end{array}$ & RGASPI. f. 17.op. 171 d. 200 \\
\hline Document 8 & $\begin{array}{l}\text { Minutes of M. P. Draule's interrogation (L.V. Nikolaev's wife). } \\
\text { December 20, 1934. Certified copy. }\end{array}$ & RGASPI. f.17.op. 171.d. 200.1.26-27 \\
\hline Document 9 & $\begin{array}{l}\text { Extract from the minutes of the meeting of the Leningrad } \\
\text { Region Party Collegium regarding the decision to impose a strict } \\
\text { reprimand to L.V. Nikolaev "for his indiscipline and philistine } \\
\text { attitude to the party mobilisation." July 2, 1934. Original. }\end{array}$ & RGASPI. f. 589. op. 3. d. 8500.1 .30 \\
\hline Document 10 & $\begin{array}{l}\text { Questionnaire sheet of the Leningrad Regional Control } \\
\text { Commission with information about L. V. Nikolaev. April } 1934 . \\
\text { Original. }\end{array}$ & RGASPI. f. 589. op. 5. d. 8500.1. 25 \\
\hline Document 11 & $\begin{array}{l}\text { L.V. Nikolaev's appeal to the Leningrad Regional Party } \\
\text { Collegium requesting to withdraw the strict reprimand against } \\
\text { him for violation of party discipline. June 2, 1934. Original. } \\
\text { Autograph. }\end{array}$ & RGASPI. f. 589. op. 3. d. 8500.1. 27-28. \\
\hline Document 12 & $\begin{array}{l}\text { Minute No. } 4 \text { from the emergency meeting of the Leningrad } \\
\text { Institute of History of the All-Union Communist Party } \\
\text { (Bolsheviks) committee addressing the issue of "The } \\
\text { Misdemeanour of Nikolaev." March 31, 1934. Original. }\end{array}$ & RGASPI. f. 589. op. 3. d. 8500. 1. 20-20ob. \\
\hline
\end{tabular}




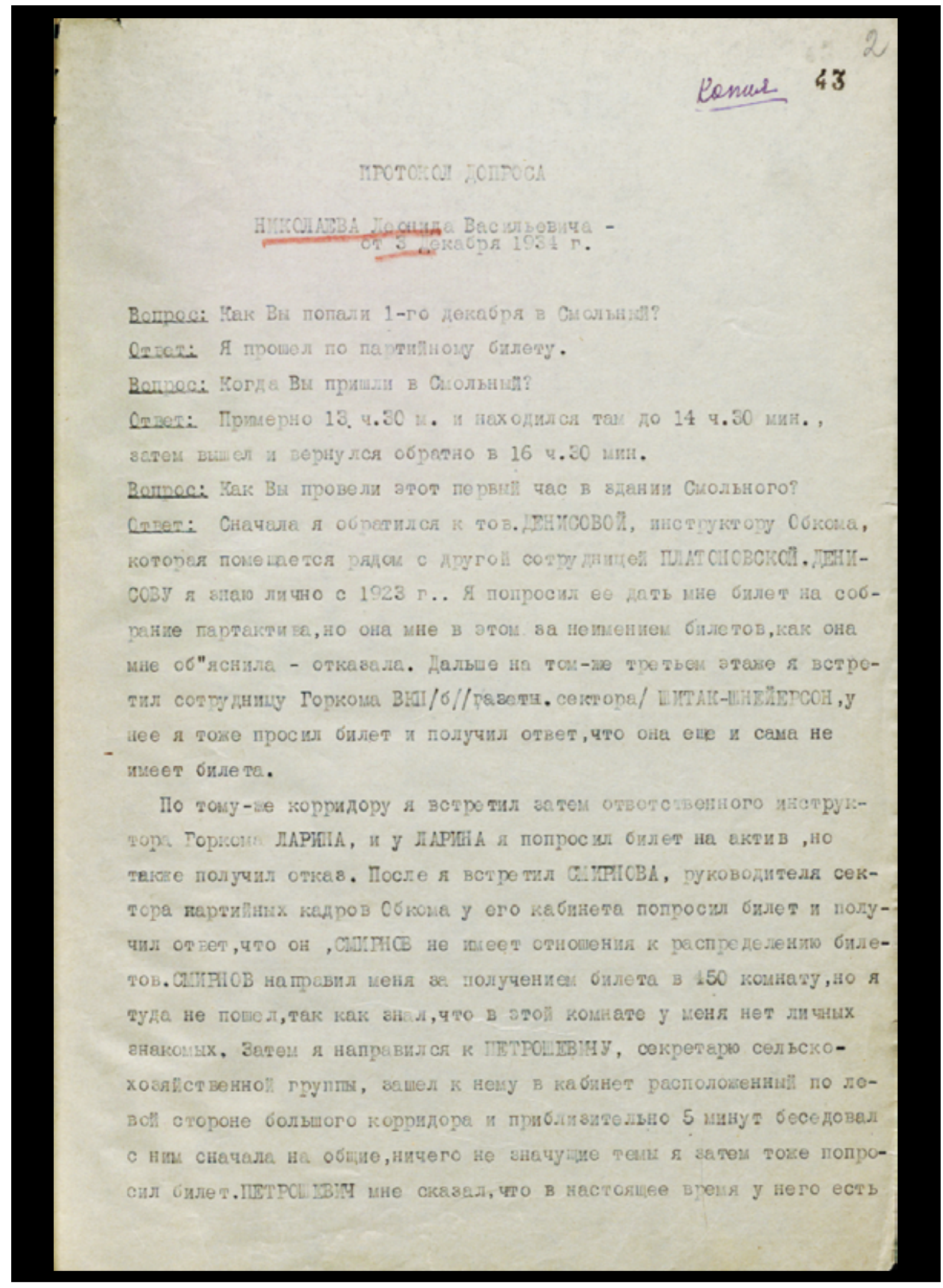




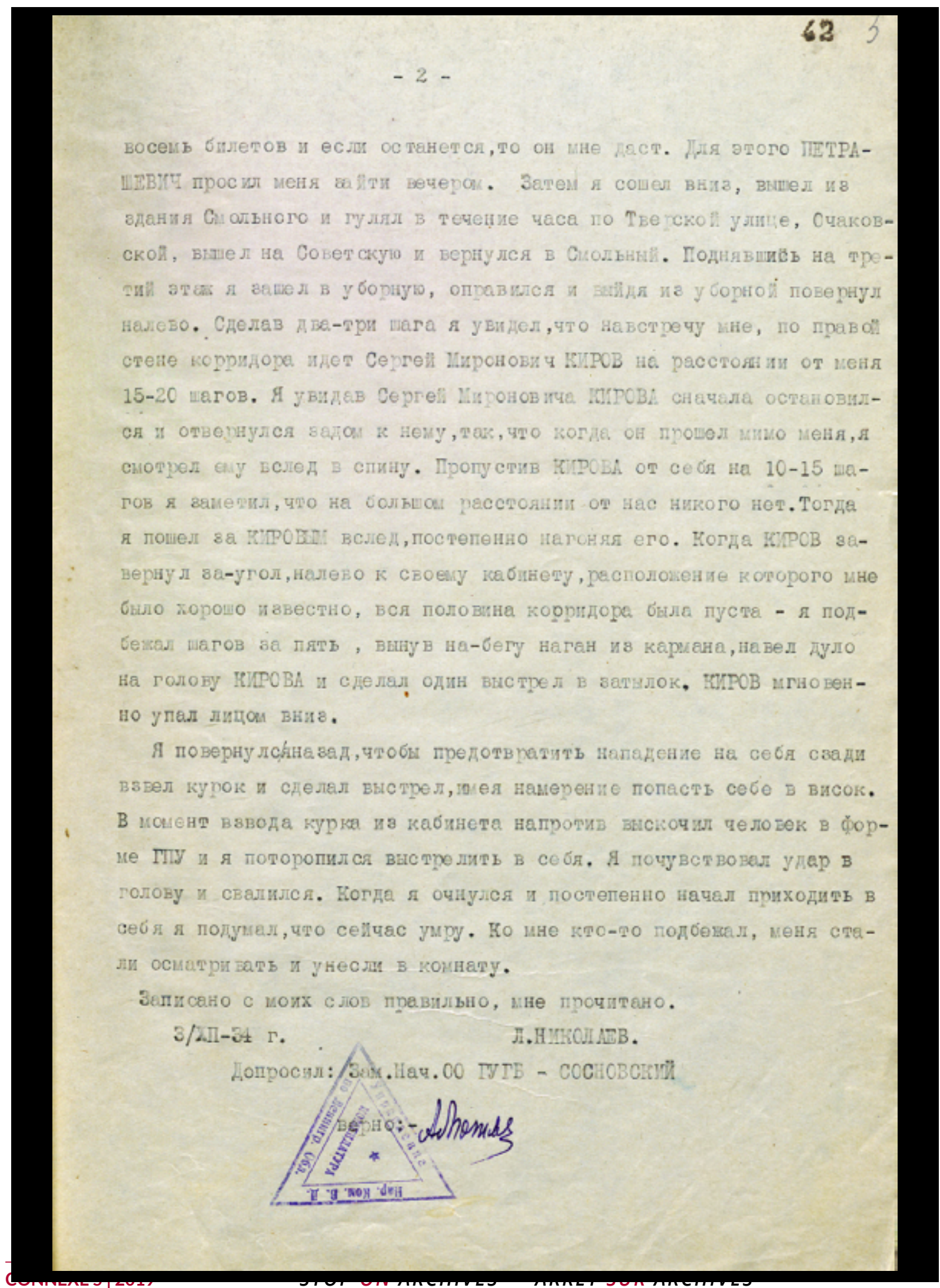


Document / документ 2

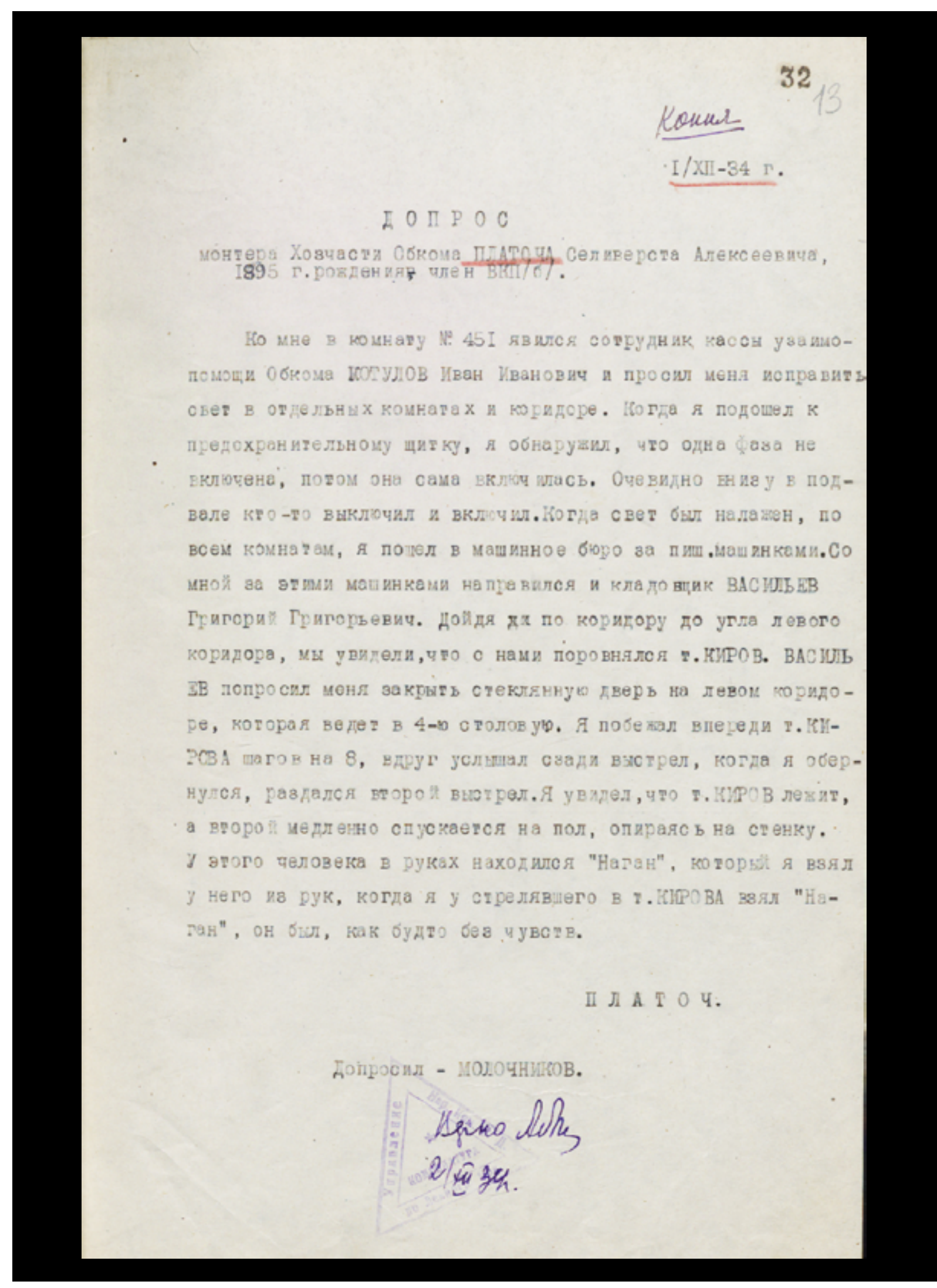


Document / документ 3

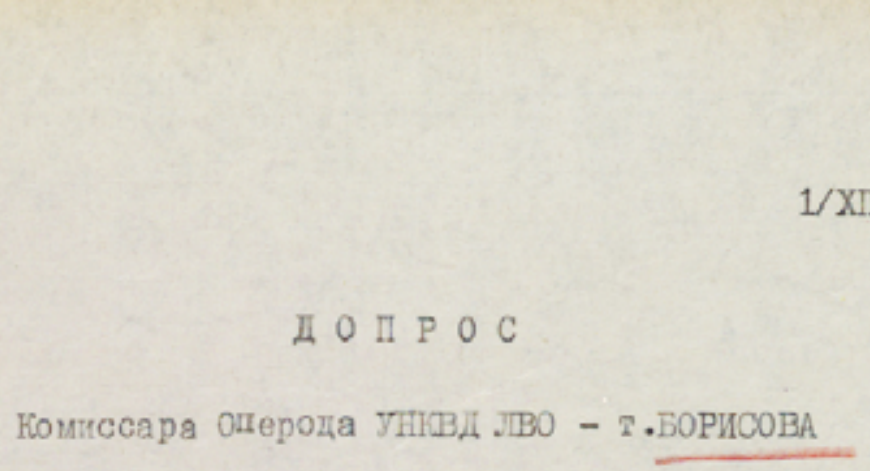

20

$\underline{K}$ 음

1/XII-1934 года.

В 4 ч. $30 \mathrm{~m}$. приблизиельно т.киров один вштел из машинв и пошел в здание овко:A. В вестибрле я попел сзади на расстоянии шагов 15 . На әтом рассгоянии я шел до второго әтажа. Когда, я встал на первої лестнипе, т.КирОВ уге бш на плошыце посередине мевду первьм is вторни әтапем, так я следовал за ним до входа на 3-д̆ этав. Добравиись до корицора, я шел по корицору от нето на расстояни 20 шагов. Не доходя двух шагов до поворога в левий корицор я услнхал внстрел. Пока я внтаци ревагьвер из кабура и навел курок, я услишал второі вистрел. выбекав на левнй қоридор, я увидел двух ленав щих у цверей приемной т. ФудОВА. Јехали они на ресстоянии $3 / 4$ метра друг от цруга. В стороне от них лежал "Наган". В том-те корицоре я

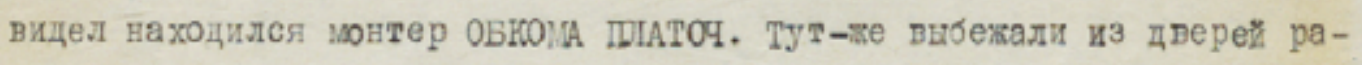
ботники ОБКОМА. ПХ Фамилии я не помно.

\section{OIEPKOA БOPИCOB}

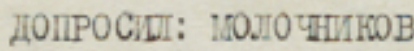

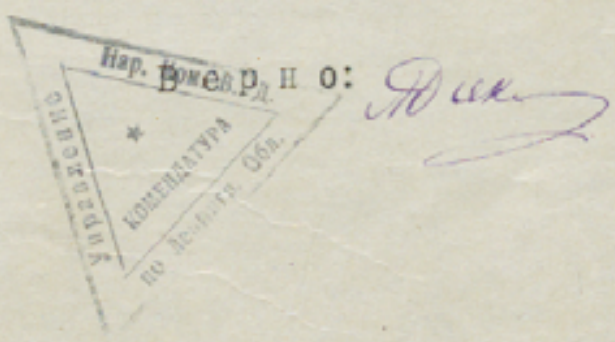




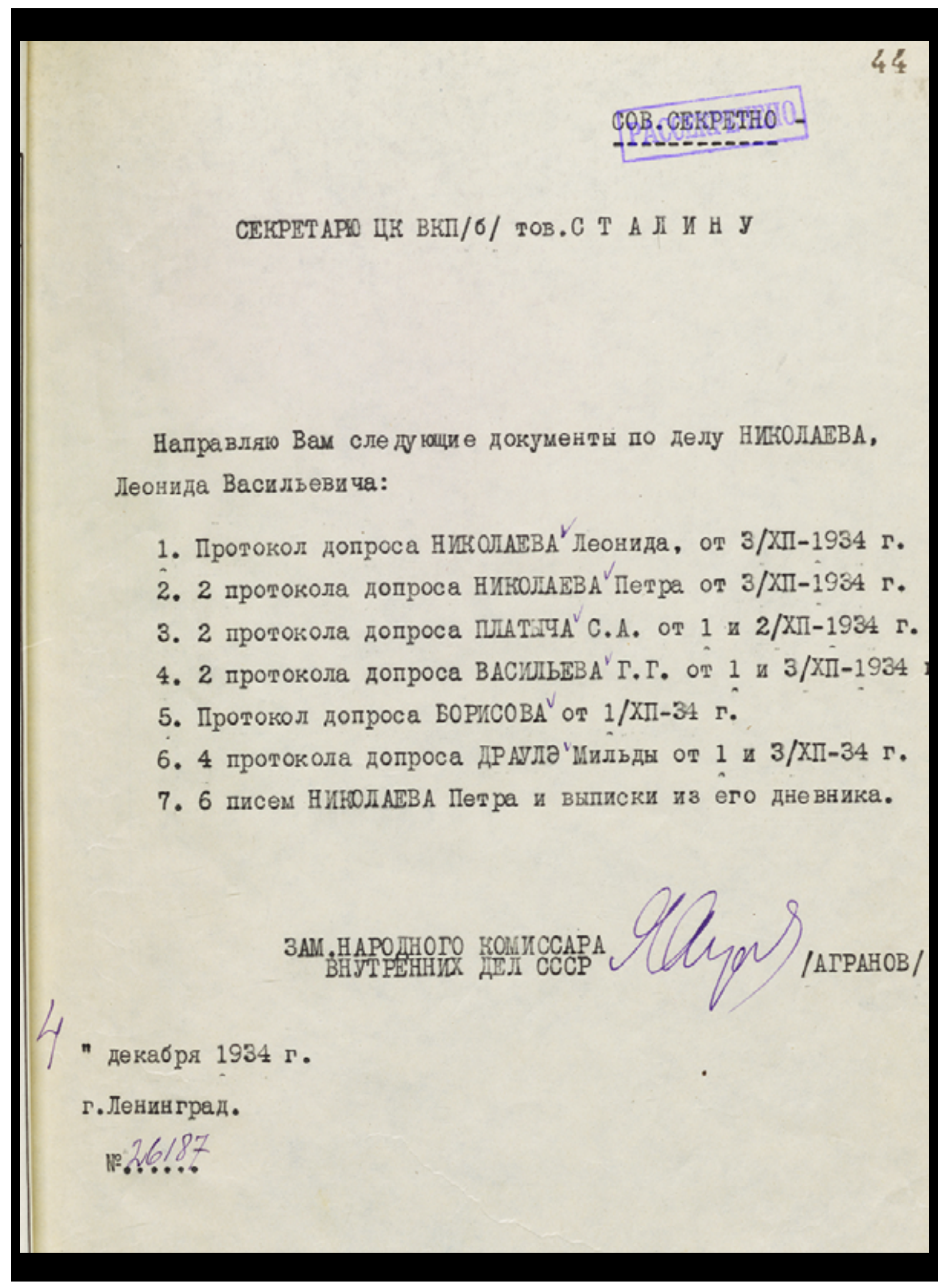




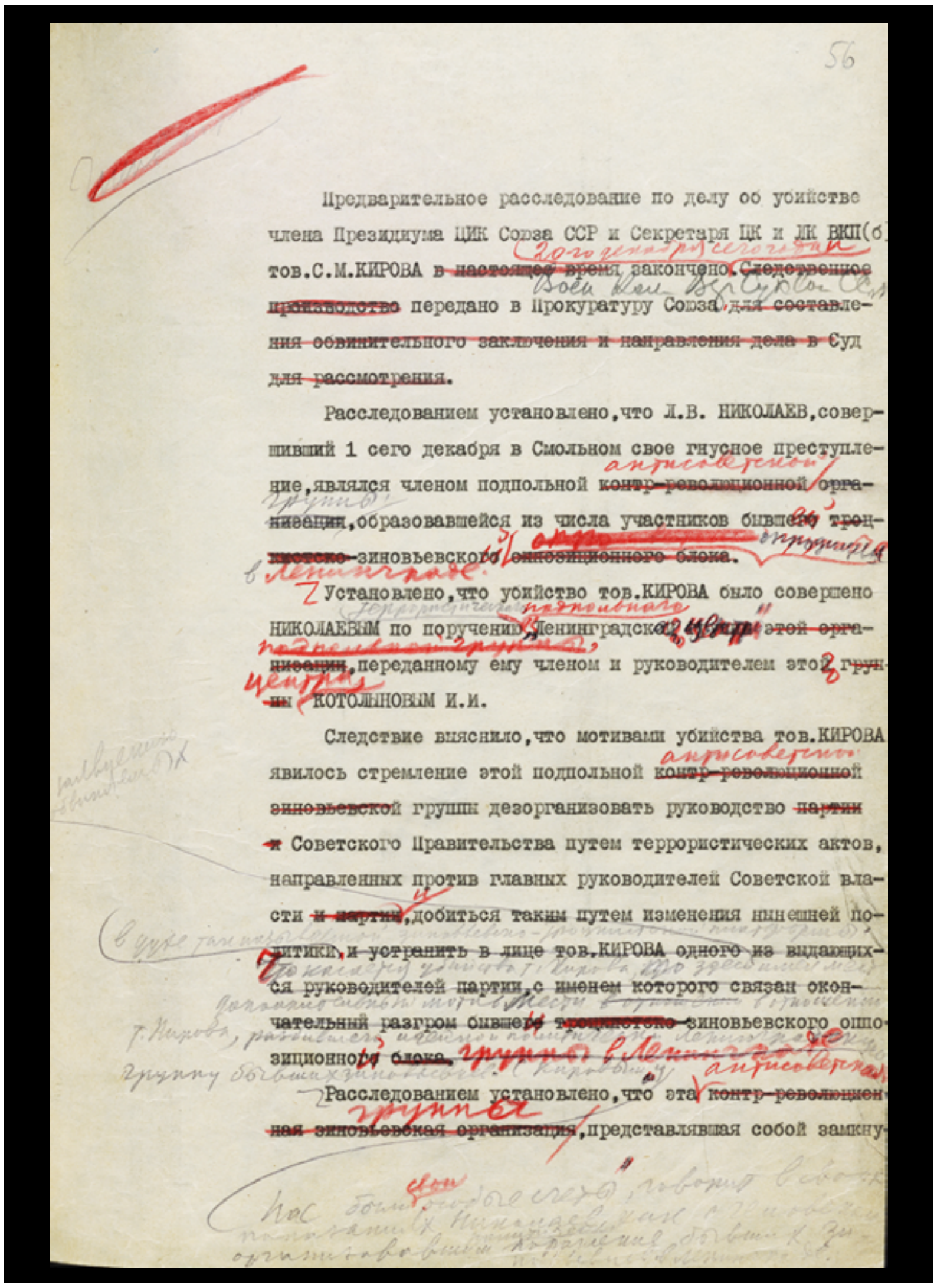


Document / документ 5.02

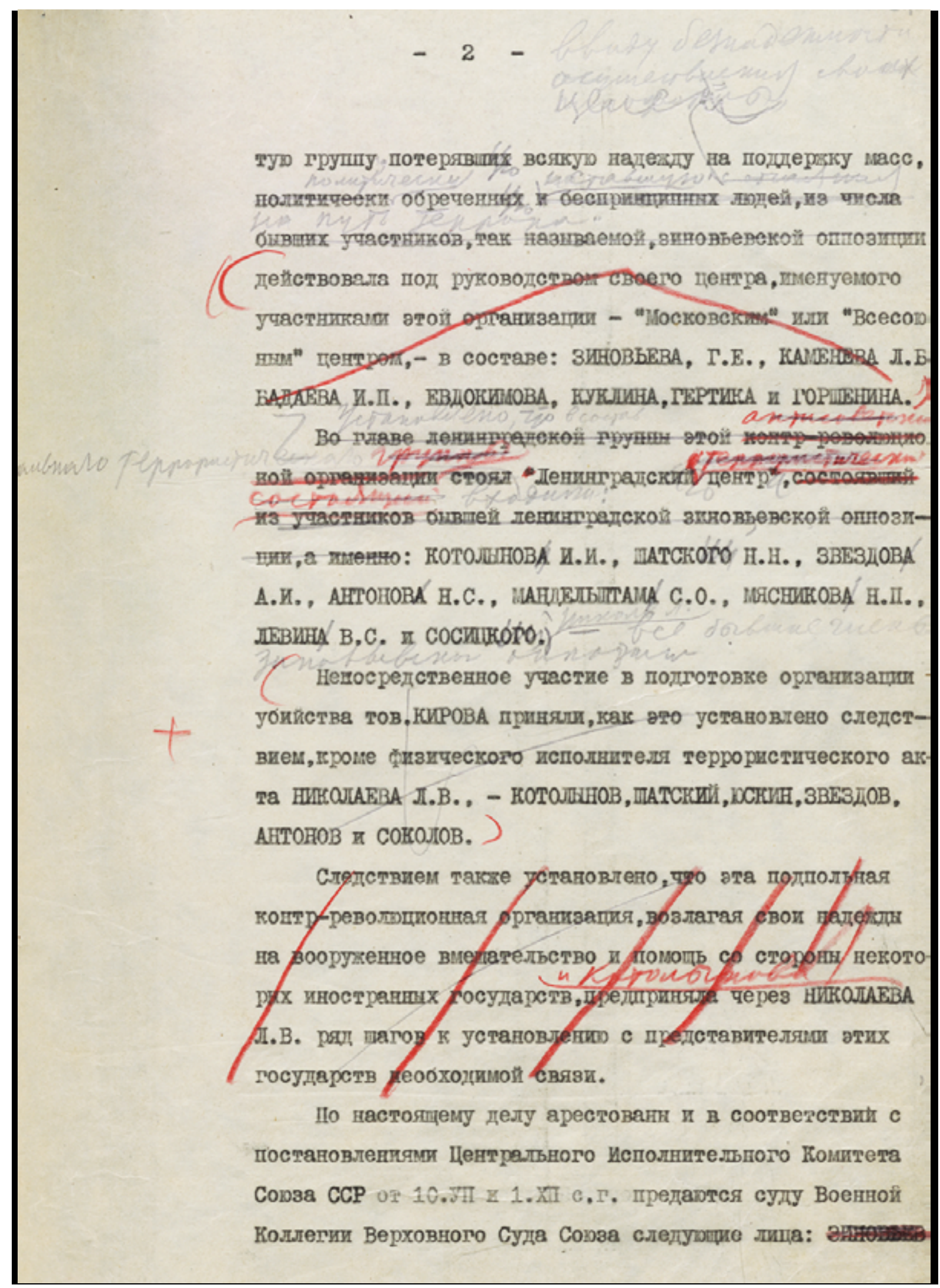

CONNEXE 5 2019 


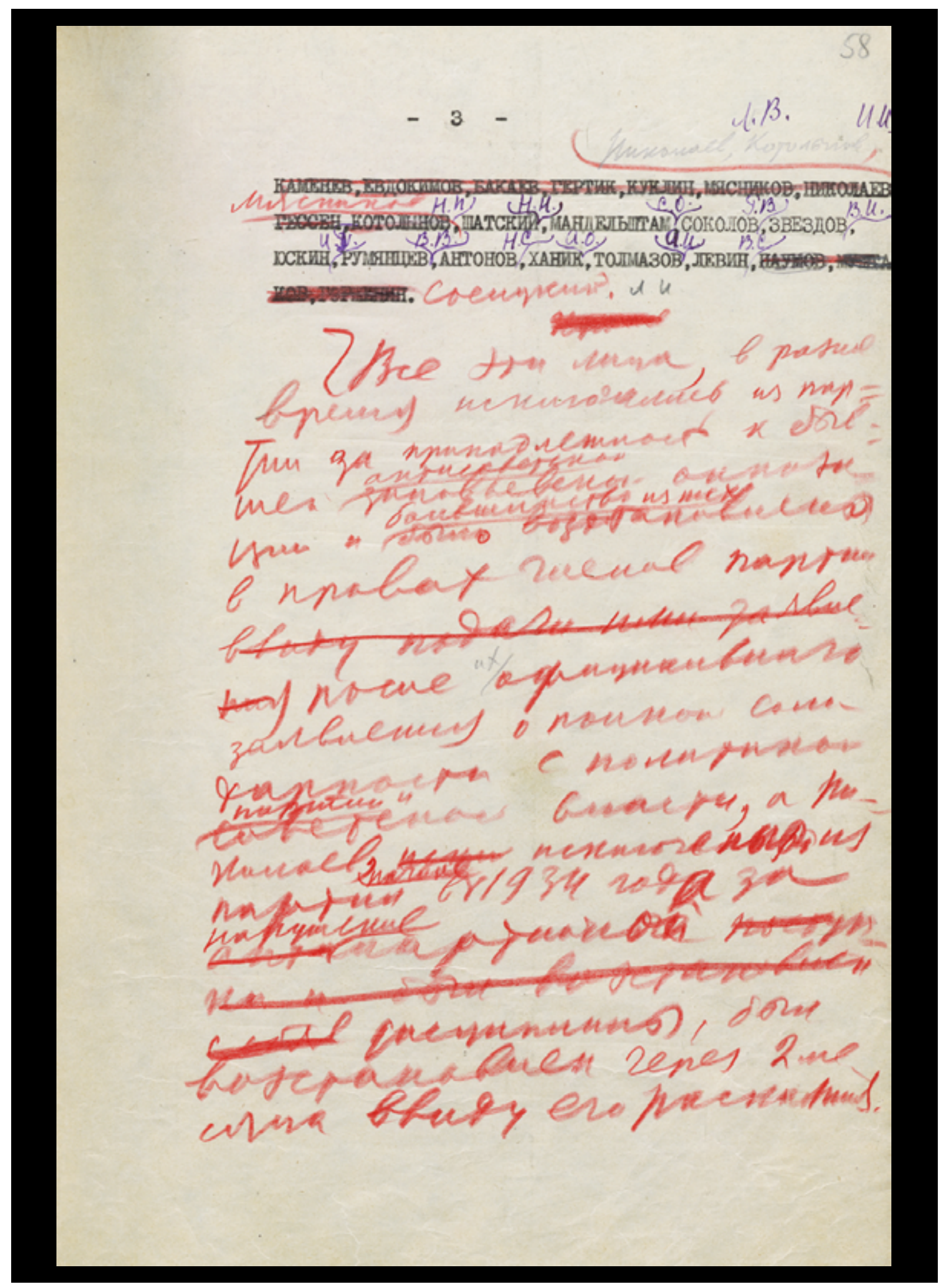




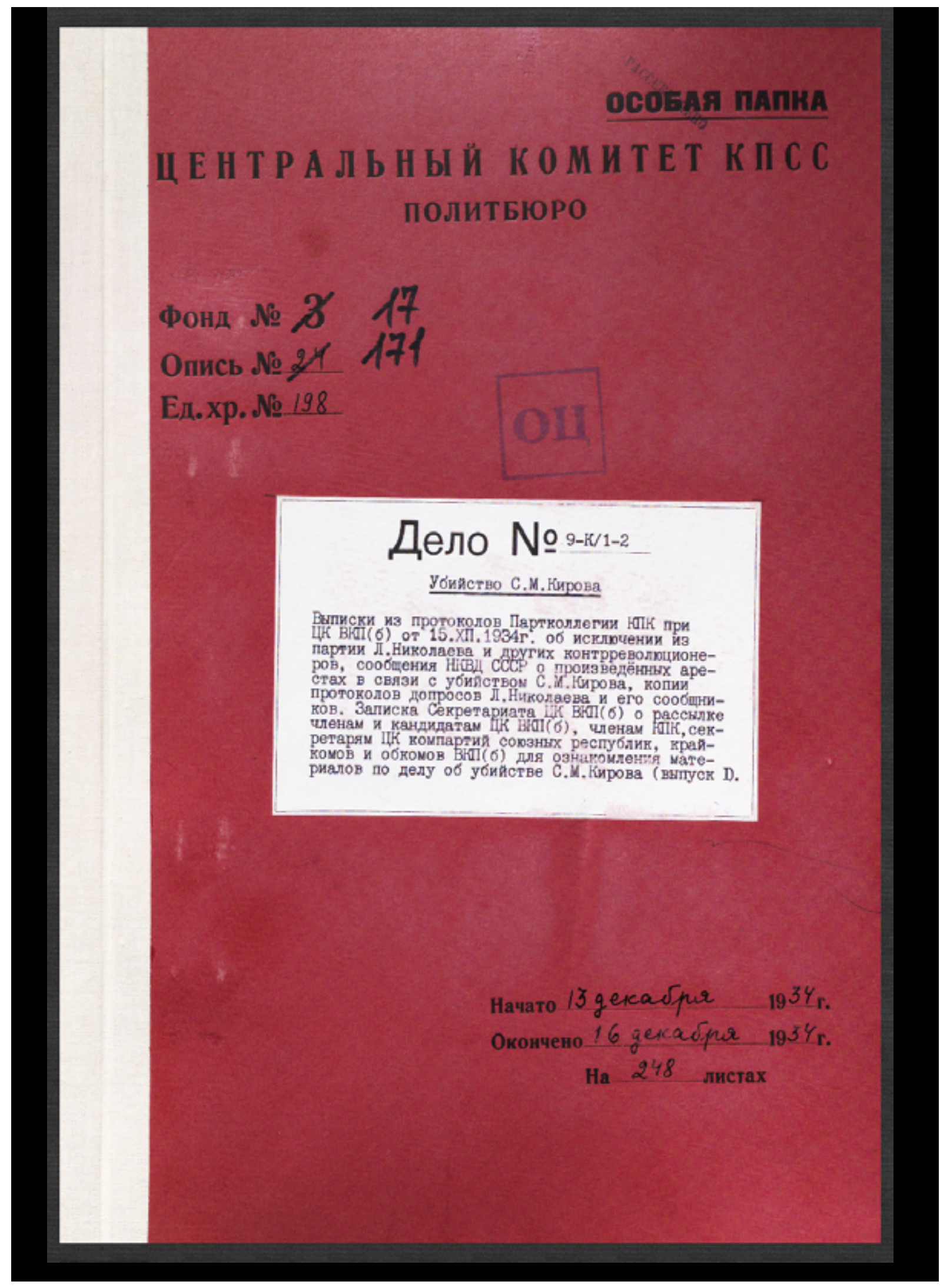


Document / документ 7

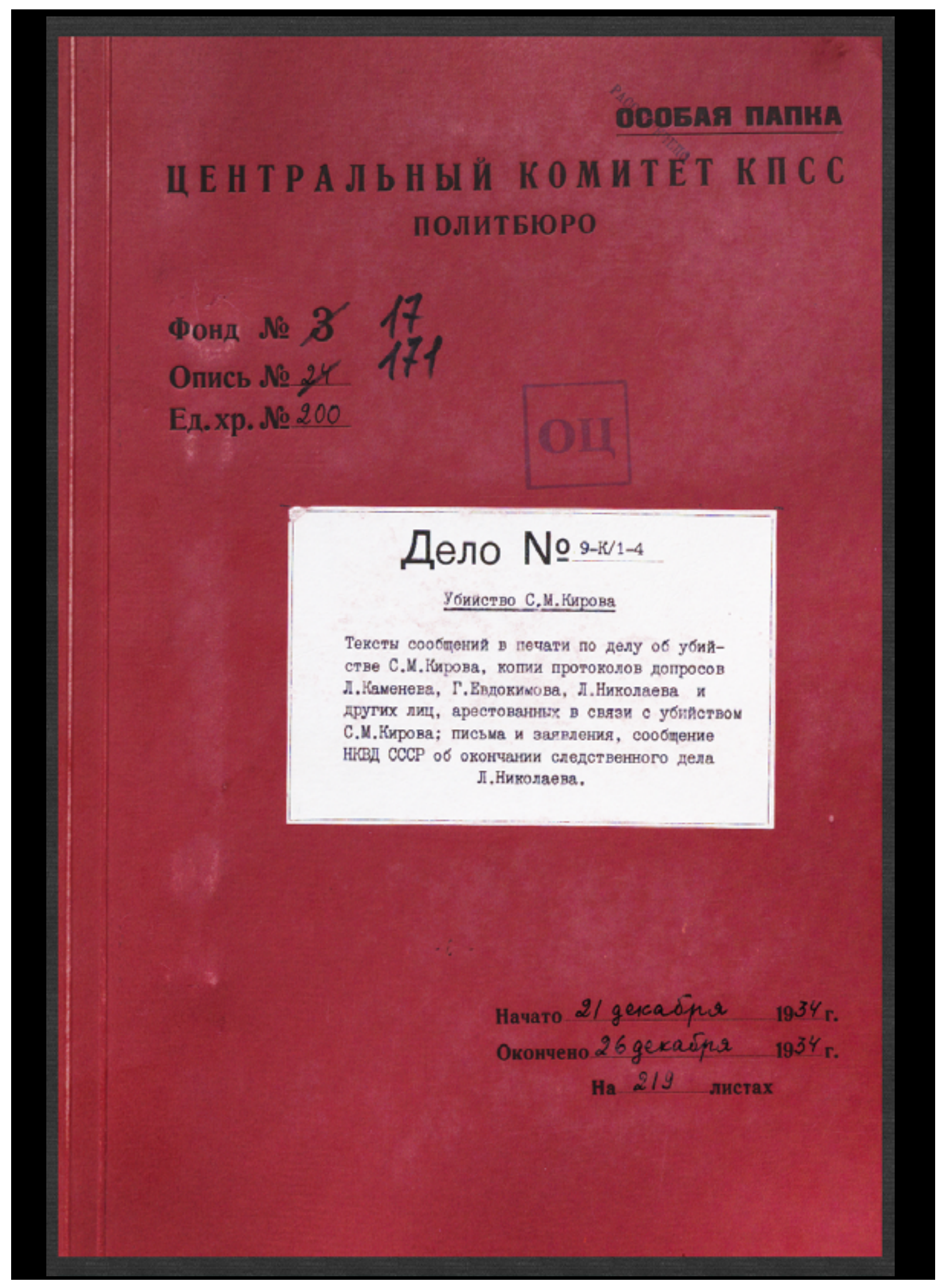


Document / документ 8.01

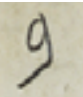

246

BII. 6 .

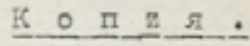

IIPOTOKOЛ IOIPOCA

य Р А Ј

$\underline{0 \mathrm{~T}} 30 . \mathrm{XI} .84 \mathrm{r}$.

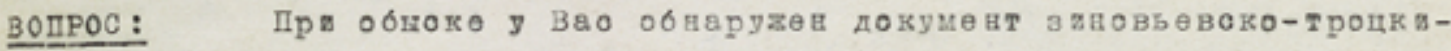

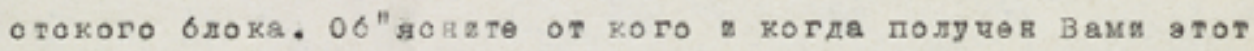
z ок ущ⿻ вт?

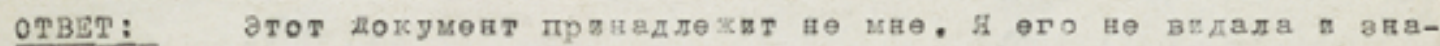

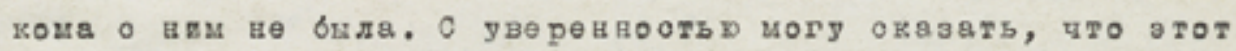

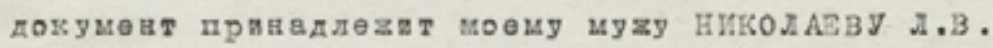

BОПРос: Извеотно ла Вам, от кого николАвв получил әтот документ?

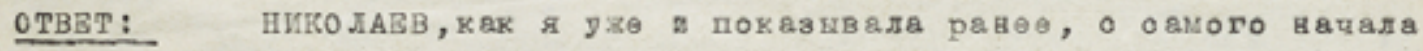
Овоей комоомолькой работв в Виооргоком райове ваходвлол

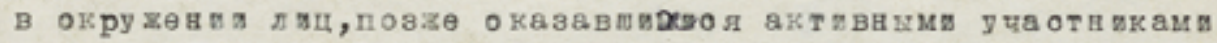
апиовьөвокой оппозвци / котолынов, ШАТский, ХАник, звзвдов, толМАвОВ в др./ В пх ореде он воопвтнвяоя и влияне этой ореды чувотвовалоов до пооледнего первода.

Поздвеө,когда ШиколАВВ пөреөхал в дугу, где ов работал

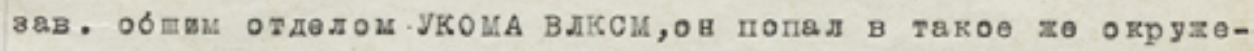

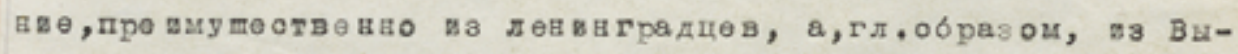
боргокого района,В первод оппоздцовной борьби воө руковод

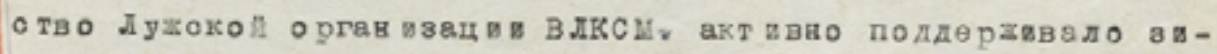

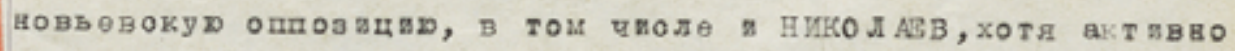
ов а ве виотупал,

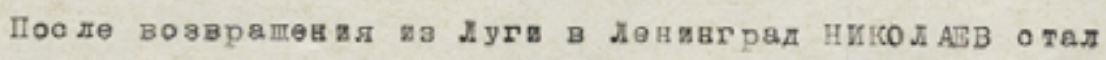

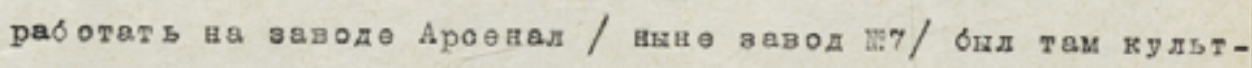
пропом дөх"ячейқ. 
Document / документ 8.02

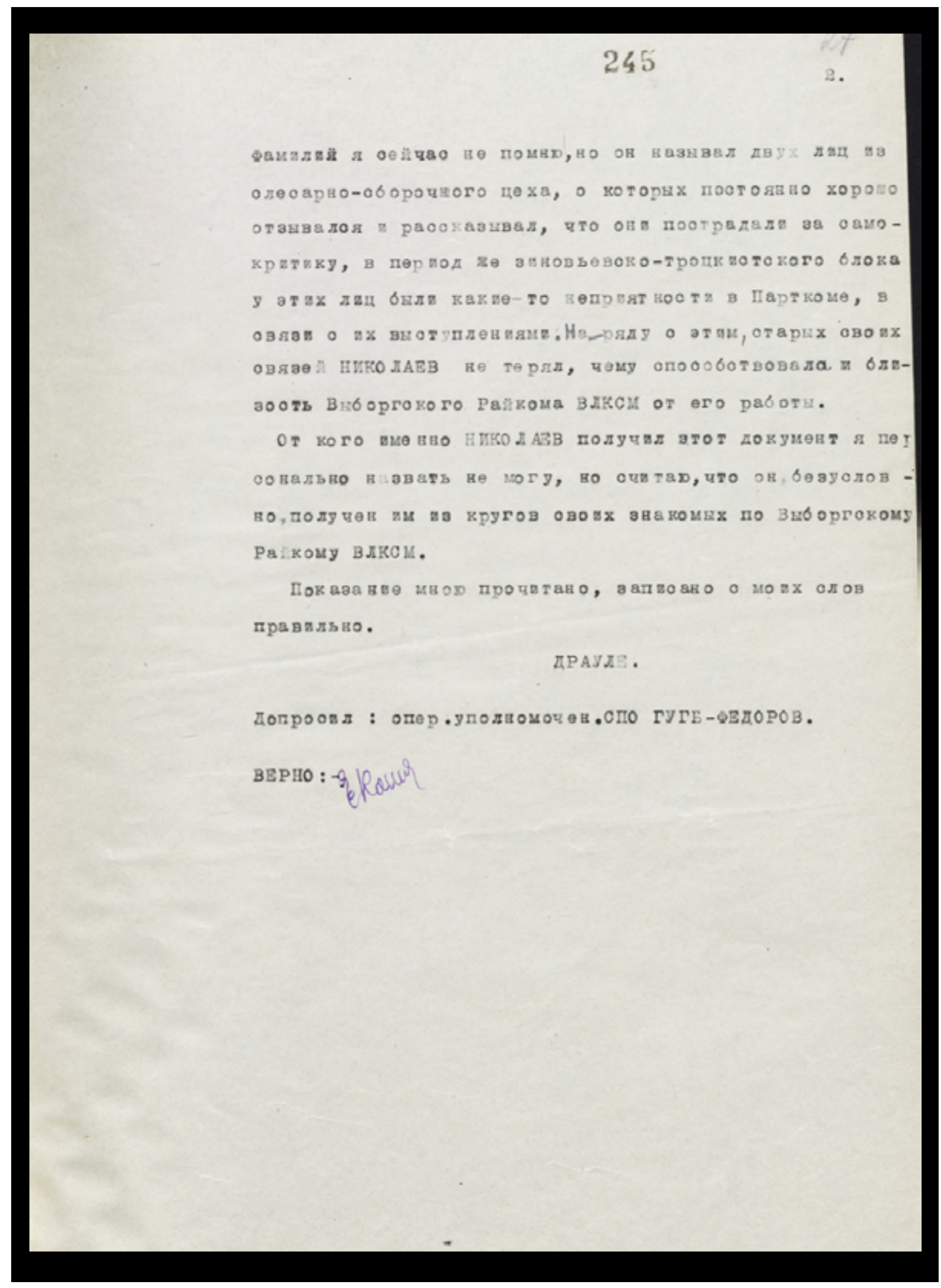


КОМИССИЯ ПАРТИЙНого КОНТРОЛЯ при ЦК ВКП (б)

ПАРТКОЛЛЕГИЯ ЛЕНИНГРАДСКОЙ ОБЛАСТИ

Ленинград, Смольный, комн. 211.

Телесіок 468-95.

N) $-134 / 2$ 20/ni $193 \%$

Вмпкеке из протоколе засопания ПАРТКОЛЛЕГИИ Лек, Обл, пр. Ne

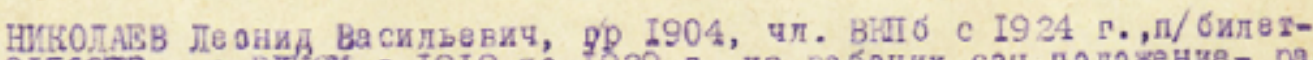

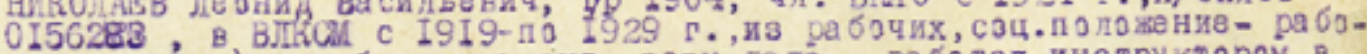

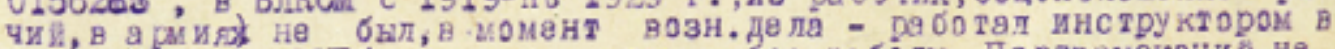
Инте Йтории ВеІІ б, в данное время без работы. Партвзасканй не имeет,

3I.I-34 г. Парткомом Хн-та истории вніб исключен из партии аa

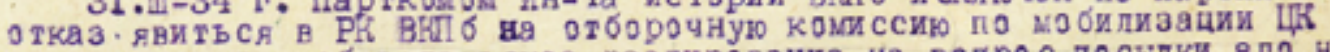
на транспорт и обыватальскоа реагирование на вопрос посылки вго на транеп орт.

29. Іу-34 г. Сыольнинским PR ВКПб во изменение решения Парткоиа,

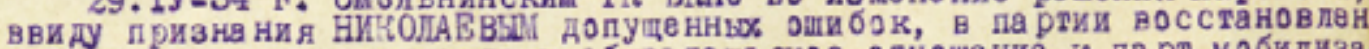
за не дисциплиниро ванность и обывательское отношение $\mathrm{K}$ па рт.мобилиза ции - об" явлен строгий ваговор с зане сением в личное дело.

Aпе лии рув $\mathrm{T}$.

докл.т. ПІ ген ганокая, присут, Николаев.

II 0 С І

Подт вердить ре пение Смольнинского PK Віліб о вынесвнии

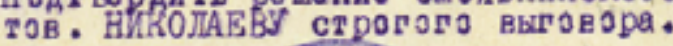

pos

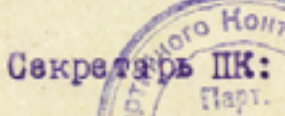




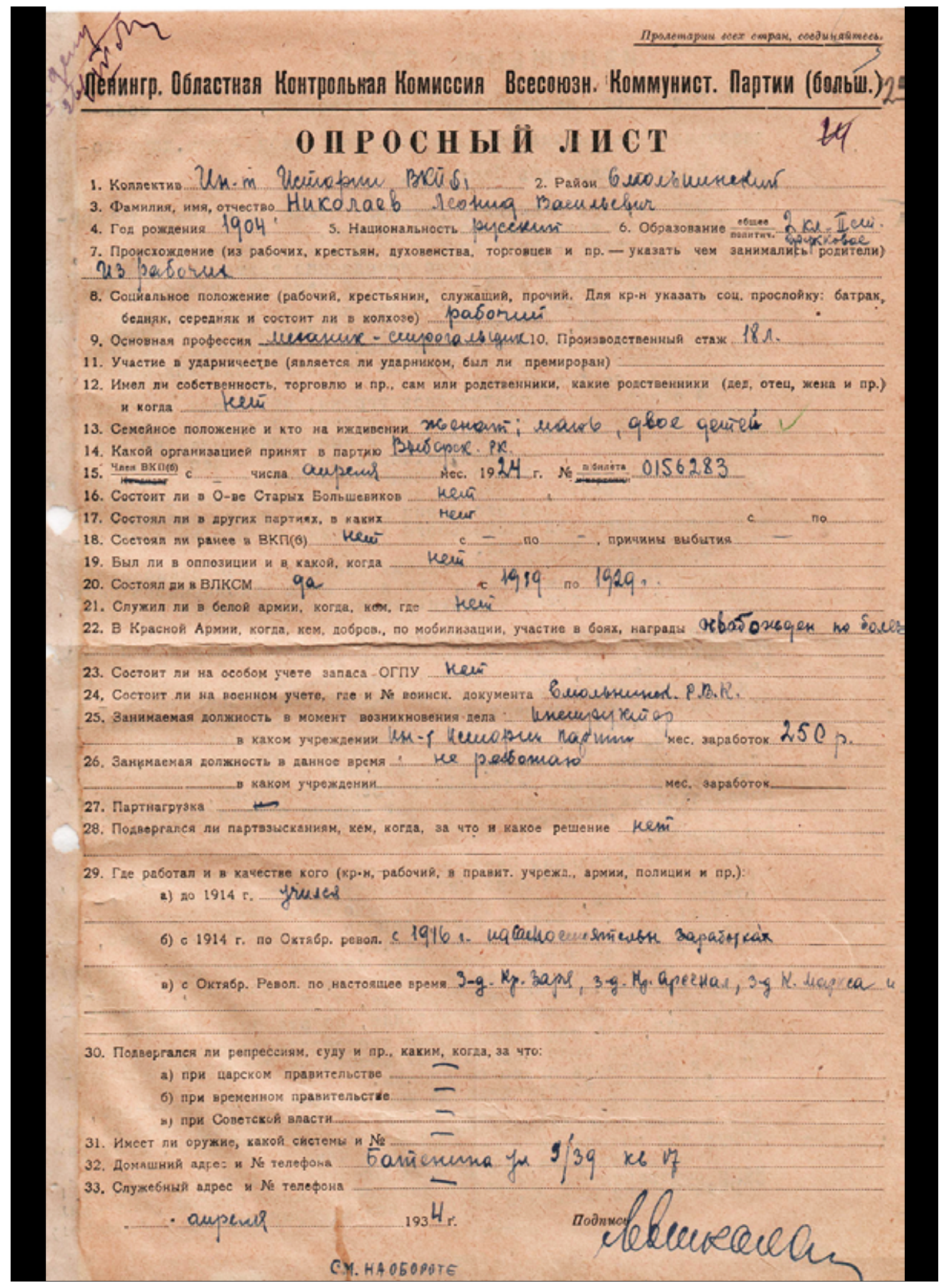




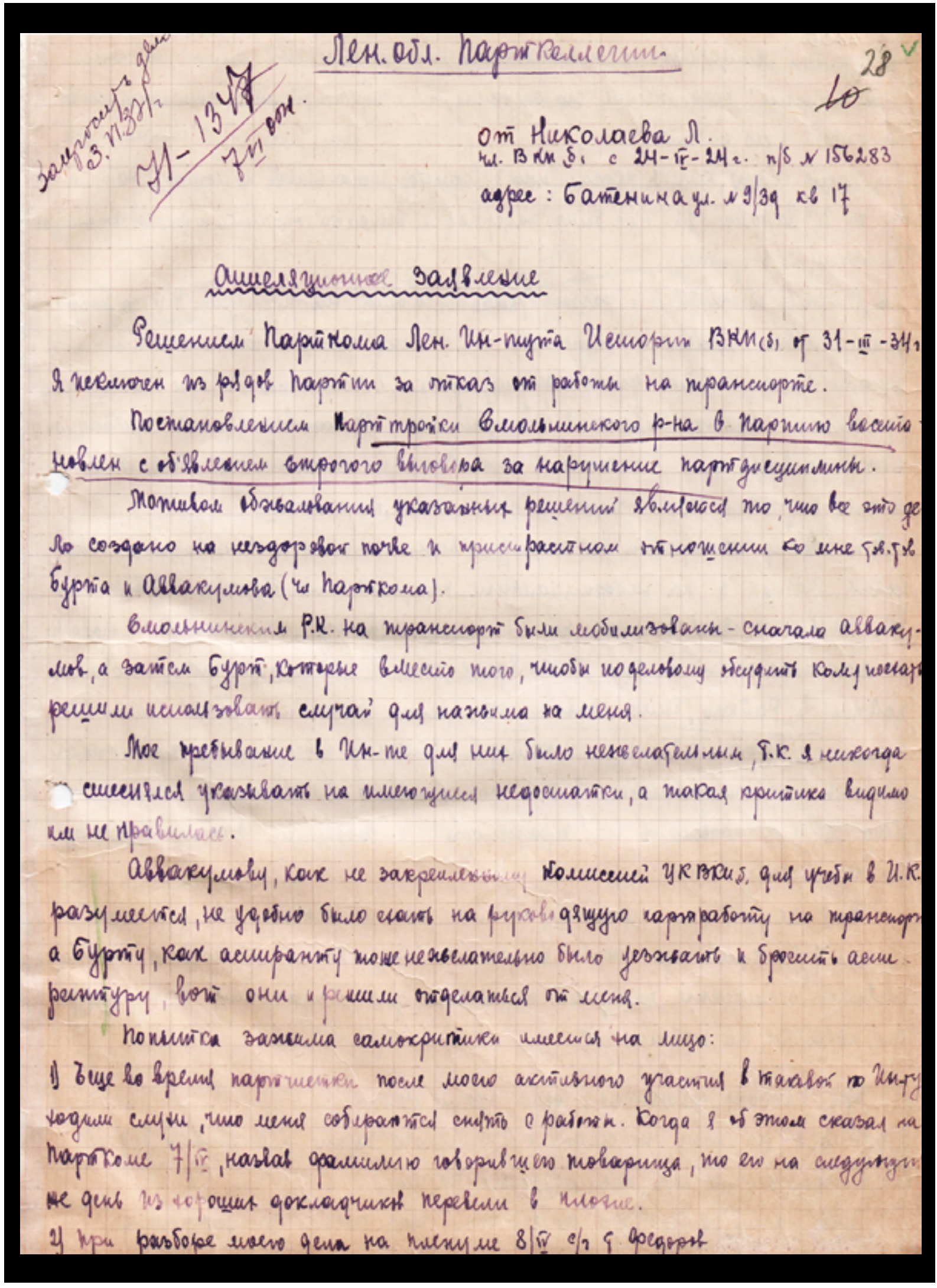




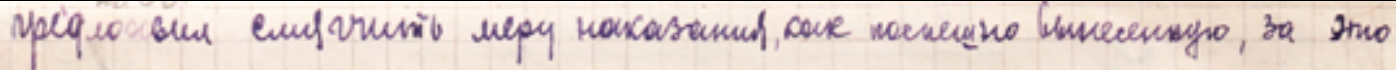

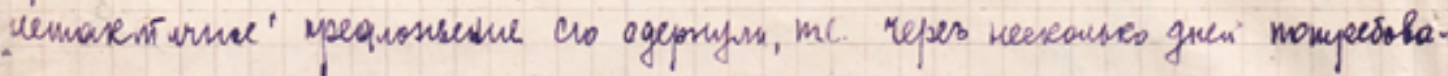
des onveni o cro pabonie.

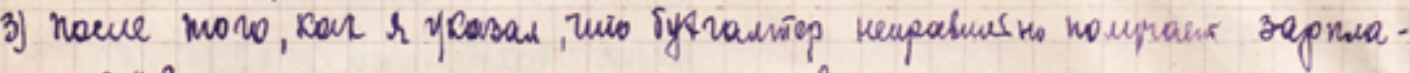

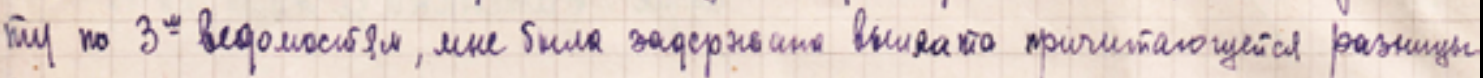
(Purenenuy mis 8 noucase).

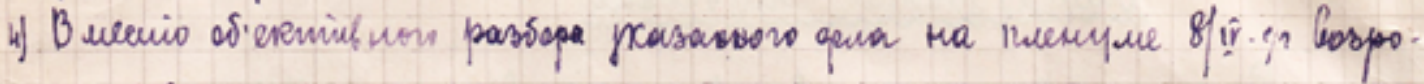

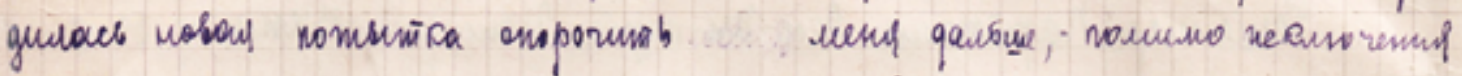

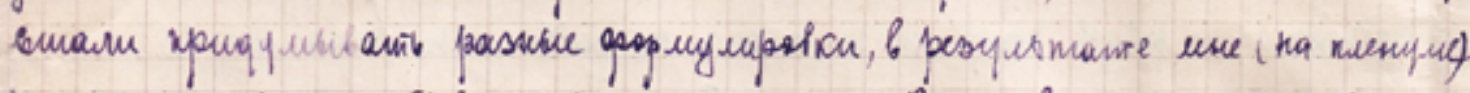

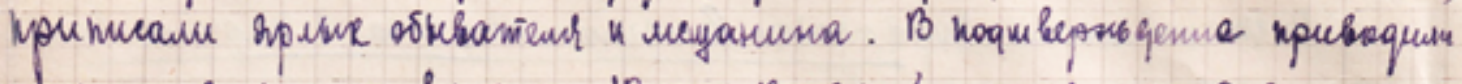

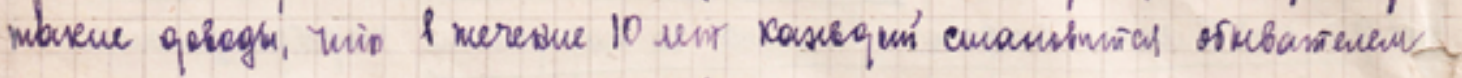

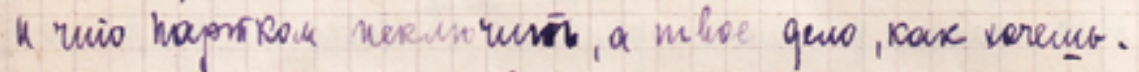

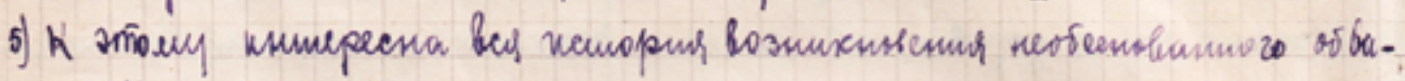

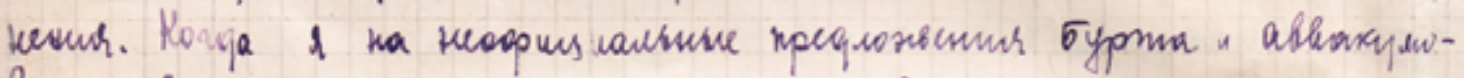

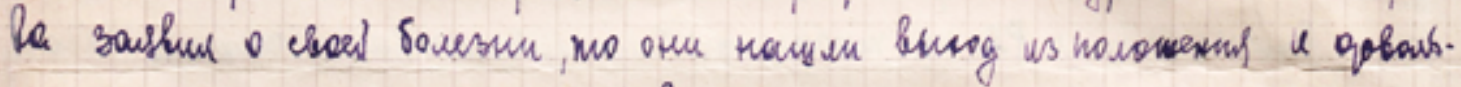

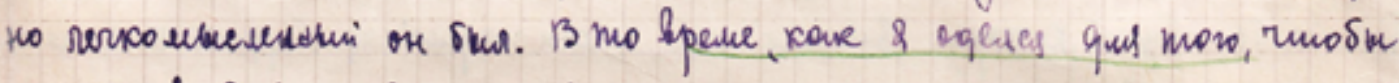

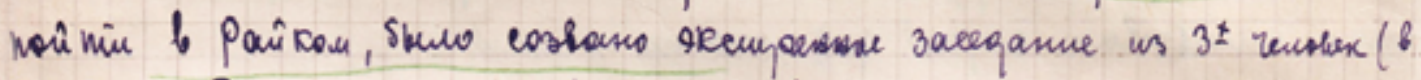

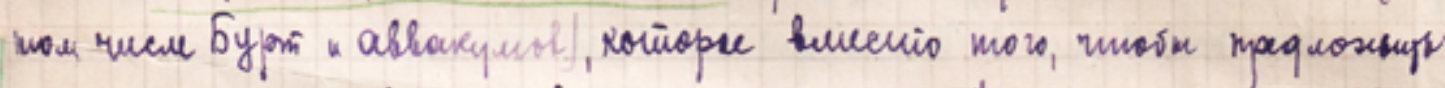

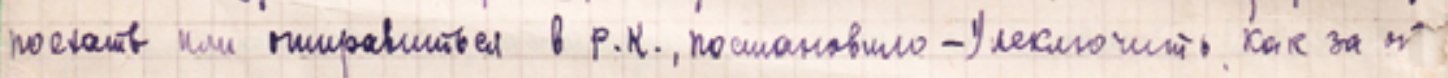

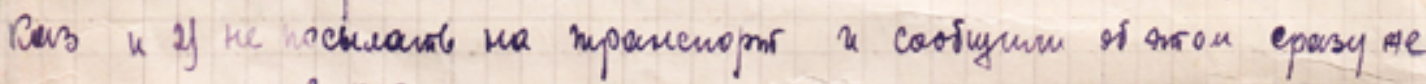
wo meveopony $b$ P. .

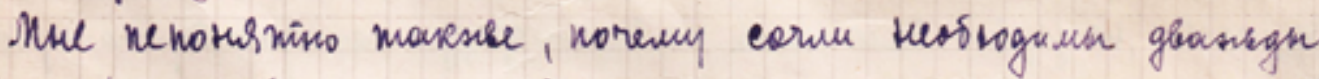

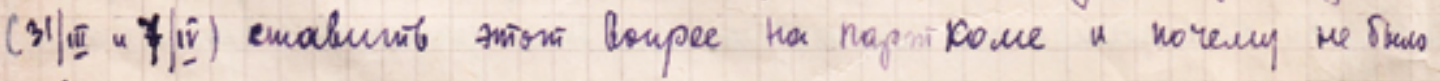

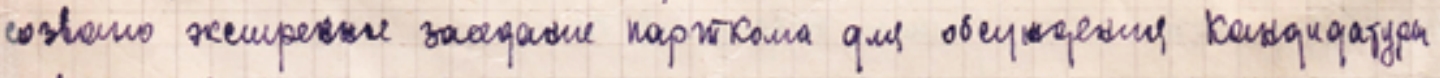

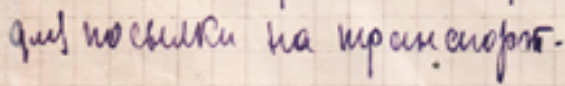

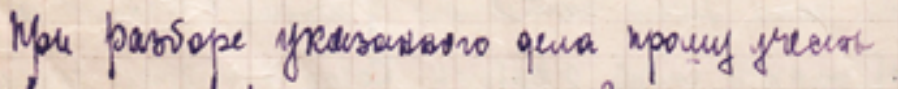

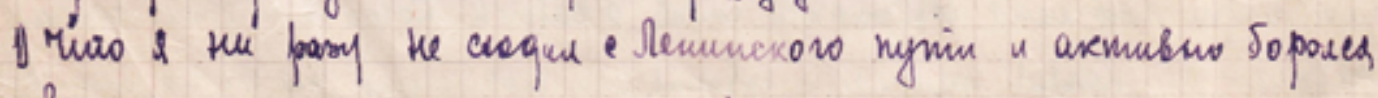

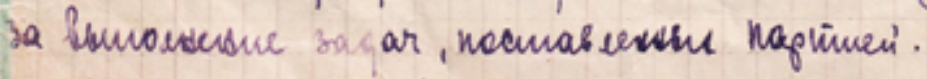

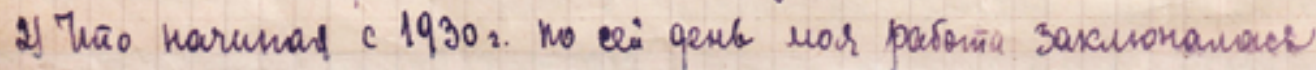




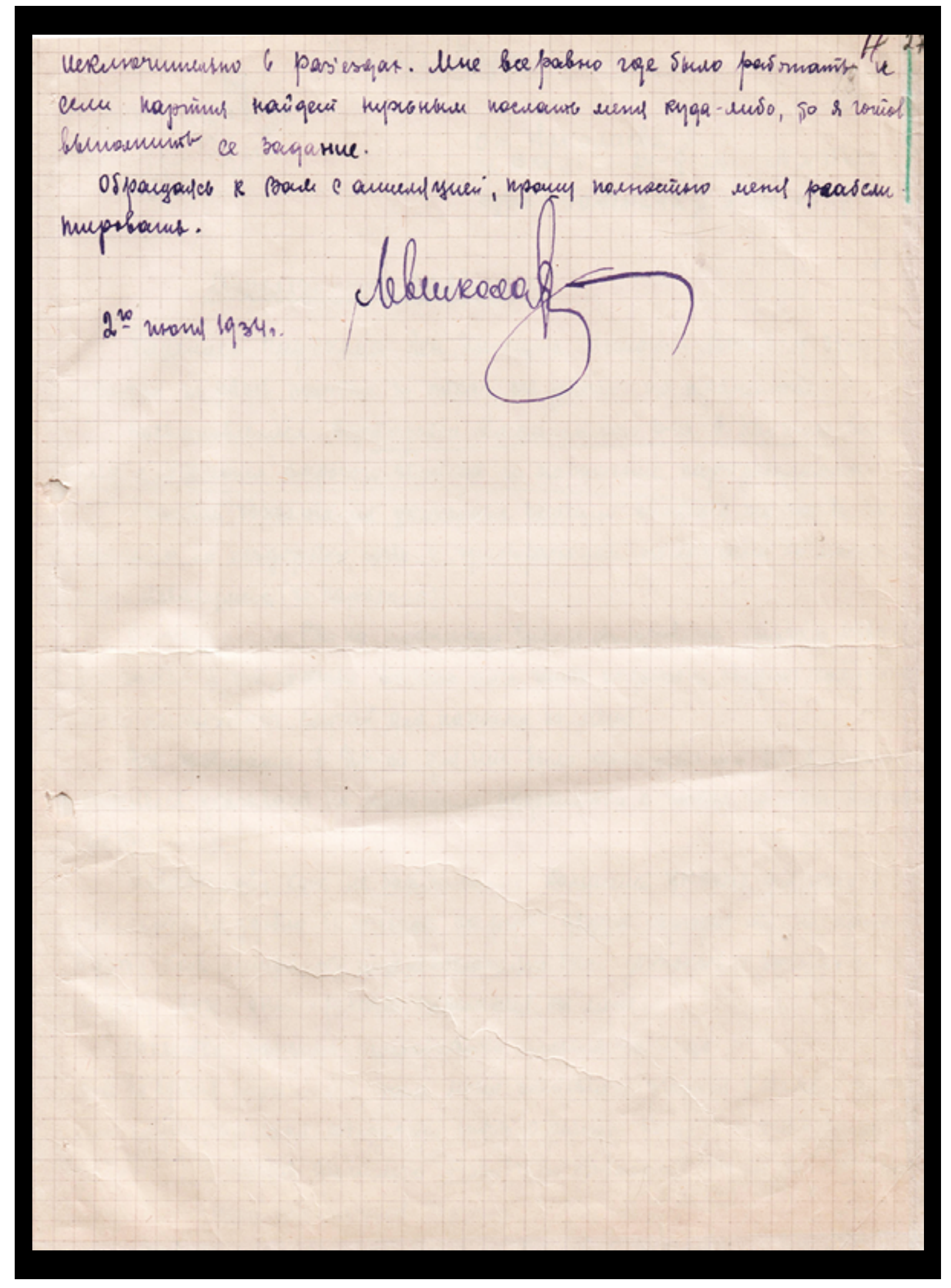


Document / документ 12.01

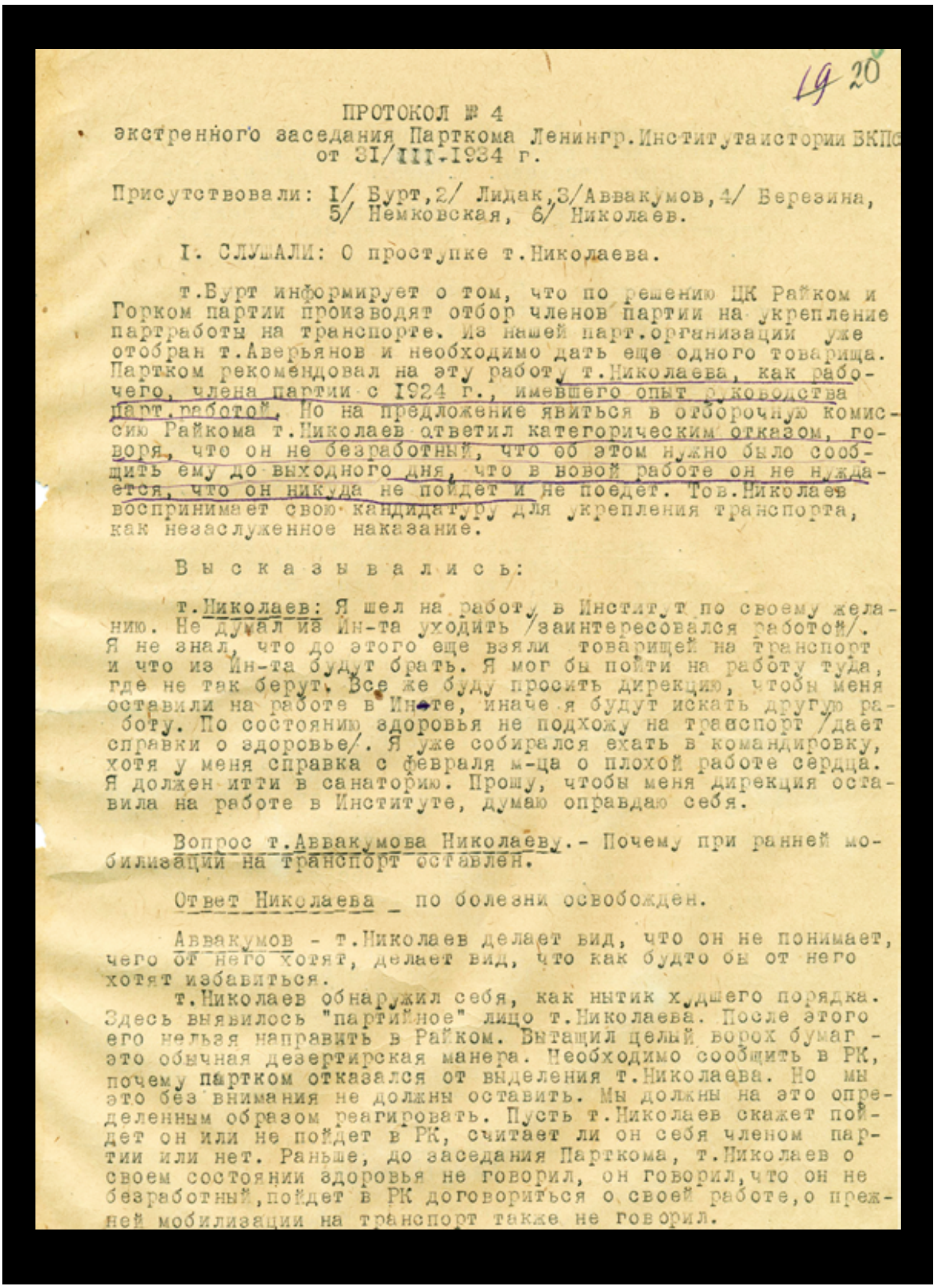


т.идак. С точки зрения партииности, поведение т. Ни

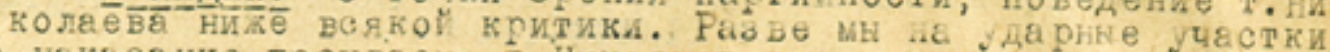
в накавание поснлаем. Т. Николаев показал себя партйно не внде ржанным.

Cеучас поселать т. Никалаева в PK нельвя. Поетупок отвратительның. Пусть т. Николаев сам скажет о своем. По туп ke.

T. Вереаиня - Я согласна с т.Лидаком и. Аввакумовнм. т. Нико गй работн. Надо внслушать т, Николаева, осовнал ли он своћ ПоОту⿰ок.

т7Бурт. - Мн п лохо знали т.Николаевя. ОН не достоин звания члена партии. т.Николаев говорил: "я не безработHeћ, әто дело не внйдет? т. Николаев. хочет работать там, где ему вигодно, Я солидарен с мнением т.Аввакуиова - Нико

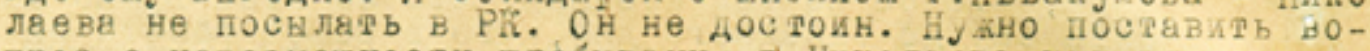
прос о невозцовности пребывания т. Николаева, как члена - ртй.

т.Николаев - Здесь далеко ввшли, но вдесь парркоиу надо Подотй объективно. Я подел т.Бестровон две Јаписки. т. Бнотпова думала, что Я. сам ухому ввиду того, что она ухо дит. 乌़ сказдл, что я не пояду потому, что я раныше посьлался на транспорт, но не подошел. La ато, й не треб ует такой срочности, еслия ва ряботу заслувил, я не могу поехать ту-

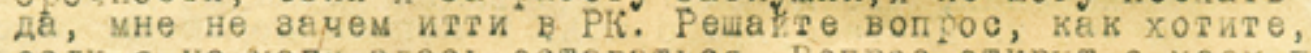
өсли я не могу здесь оставяться. Вопрос откркт о моем IIpeбевании в Ин-те. Мне нужна искать работу в PK. g на трада-

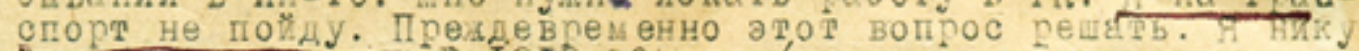

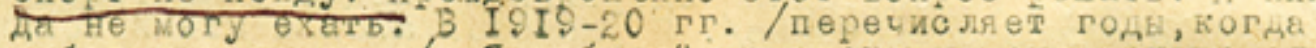
работал в деревне/. Я ивбитыи человек, у меня меньше здо-

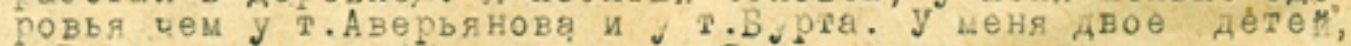
y. Вас наверное ни у кого нет. Я могу итти на коопеgятивну работу. В Сибири полгде рабогал, но вернули. Вросьте меня запугиветь, больного человека ив партии не искличашт.

т.Лидак . - Поведение и рассухдения т. "иколаева тако-Ву, чеб нам ничего не остаетея, как исклочить Николявва из пертии.

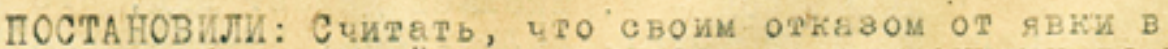
отбопочную комисеив райкои и своими рассуддениями до и на а аседании Перткома, как то: "Я не безработнй, в новой

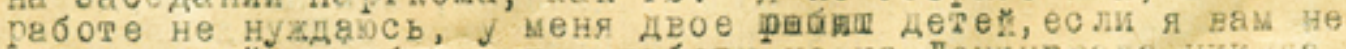

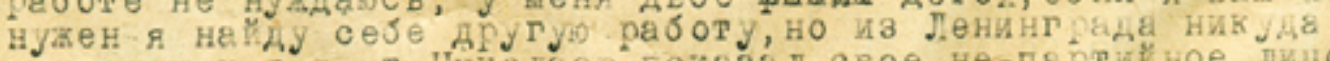
не поеда и г... т. Николие покааи л свое не-партйное лицо,

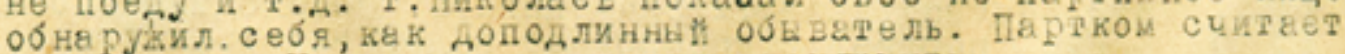
необтодимем Николаева из партии исключить.

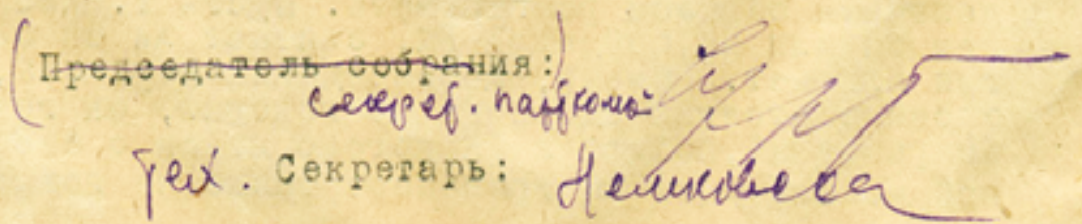

